NBER WORKING PAPER SERIES

INTANGIBLE INVESTMENT AND FIRM PERFORMANCE

Nathan Chappell

Adam B. Jaffe

Working Paper 24363

http://www.nber.org/papers/w24363

\author{
NATIONAL BUREAU OF ECONOMIC RESEARCH \\ 1050 Massachusetts Avenue \\ Cambridge, MA 02138 \\ March 2018
}

This research is partially funded by the Productivity Hub under the Productivity Partnership programme, and by Queensland University of Technology. We would like to thank Lawrence J. White and an anonymous referee for valuable feedback. We also thank participants at an internal Motu seminar, as well as participants at a Productivity Commission of New Zealand workshop for helpful comments. The paper was prepared for a special issue of Review of Industrial Organization in honour of Mike Scherer, edited by David Audretsch, Al Link and John Scott. We thank the editors for the opportunity to participate in the special issue. The views expressed herein are those of the authors and do not necessarily reflect the views of the National Bureau of Economic Research.

NBER working papers are circulated for discussion and comment purposes. They have not been peer-reviewed or been subject to the review by the NBER Board of Directors that accompanies official NBER publications.

(C) 2018 by Nathan Chappell and Adam B. Jaffe. All rights reserved. Short sections of text, not to exceed two paragraphs, may be quoted without explicit permission provided that full credit, including $(\odot$ notice, is given to the source. 
Intangible Investment and Firm Performance

Nathan Chappell and Adam B. Jaffe

NBER Working Paper No. 24363

March 2018

JEL No. D22,D24,L21

\begin{abstract}
$\underline{\text { ABSTRACT }}$
We combine survey and administrative data for about 13,000 New Zealand firms from 2005 to 2013 to study intangible investment and firm performance. We find that firm size and moderate competition is associated with higher intangible investment, while firm age is associated with lower intangible investment. Examining firm performance, we find that higher investment is associated with higher labour and capital input, higher revenue, and higher firm-reported employee and customer satisfaction, but not with higher productivity or profitability. The evidence suggests that intangible investment is associated with growth and 'soft' performance objectives, but not with productivity or profitability.
\end{abstract}

Nathan Chappell

Motu Economic and Public Policy Research

Level 1, 97 Cuba St

Wellington 6011

New Zealand

Nathan.Chappell@motu.org.nz

Adam B. Jaffe

Motu Economic and Public Policy Research

PO Box 24390

Wellington 6142

New Zealand

and Queensland University of Technology

and also NBER

adam.jaffe@motu.org.nz 


\section{Intangible Investment and Firm Performance}

\section{Abstract}

We combine survey and administrative data for about 13,000 New Zealand firms from 2005 to 2013 to study intangible investment and firm performance. We find that firm size and moderate competition is associated with higher intangible investment, while firm age is associated with lower intangible investment. Examining firm performance, we find that higher investment is associated with higher labour and capital input, higher revenue, and higher firm-reported employee and customer satisfaction, but not with higher productivity or profitability. The evidence suggests that intangible investment is associated with growth and 'soft' performance objectives, but not with productivity or profitability.

\section{$1 \quad$ Introduction}

Throughout his career, F. M. Scherer was interested in the determinants of firm performance, including how strategy and investment decisions -- particularly related to technology and innovation -- contributed to performance. The possible importance of management and R\&D in productivity is an aspect of a broader developing realization of the importance of intangible investment in firm performance (Corrado et al., 2009; Corrado et al., 2012; Bontempi and Mairesse, 2015).

We can think of firms as having stocks of intangible capital of various kinds, in the form of: knowledge about production possibilities; practices and procedures; strategies; organizational structures; etc. Intangible investment increases these stocks, just as traditional investment increases traditional capital such as machines and structures. And an increase in intangible capital should increase firm output and the productivity of labour, in a manner that is analogous to that resulting from increases in tangible capital.

If we could measure the stocks of intangible capital, we could include them in estimating production functions for firms, and estimate their effect on output and their rates of return. But 
if we don't include them in the production function, then their impact on output flows through to the "residual" or the productivity of the firm. This means that, in principle, observed differences in productivity could be due to underlying differences in the extent of intangible investment. Similarly, since we would expect firms to earn a return on their intangible investment, the profitability of the firm-measured in the traditional manner as profits relative to the value of traditional capital—should be increased by intangible investment.

An alternative view could be that firms engage in intangible investment (e.g. employee training, organizational restructuring, new product designs) in response to perceived weakness or threats to the business. While this possibility is not inconsistent with such investment's having a productivity and profitability payoff, it suggests that observed investment might be concentrated in poorly performing firms and perhaps is thereby obscuring an underlying positive causal effect of intangible investment on productivity. ${ }^{1}$

In this paper, we try to untangle the relationships among intangible investment, firm characteristics and environment, and firm performance, with the use of New Zealand firm-level survey data on intangible investment that is linked to administrative and tax records of firm performance and characteristics. We examine both the characteristics of firms that are associated with intangible investment, and what firm performance looks like subsequent to such investment.

To preview our findings: The results suggest that -- when we compare firms within a narrowly defined industry -- intangible investment is highest in larger firms, younger firms, and firms that face moderate competition in the marketplace. Contrary to the prediction from the simple version of the investment story, we find no evidence that higher intangible investment is associated with higher productivity or higher profitability. Subsequent to reporting intangible

\footnotetext{
${ }^{1}$ By analogy, the building fires to which the most fire engines are sent are also the ones in which the largest amount of property damage occurs. It is likely that, holding constant the initial intensity of the fire, sending more engines reduces the amount of damage. But that relationship is obscured by the 'reverse causality' running from fire damage to number of engines.
} 
investment, firms appear to increase spending on both capital and labour, and they report an increase in deflated revenue; but the rates of increase of inputs and outputs are such that measured productivity and profitability do not increase. Consistent with this "growth without profit" picture, we find some evidence that intangible investment is associated with subsequent improvement in 'soft' aspects of firm performance such as firm-reported customer and employee satisfaction.

Because all of our variables are determined jointly by the decisions of the firm, it is very difficult to draw causal inferences with regard to the empirical associations we have found. Nonetheless, we have sliced the data many different ways and found little evidence of intangible investment's contributing positively to productivity in New Zealand. Further, we find no evidence that firms that invest in intangibles are underperformers before undertaking the investment, so it appears unlikely that a positive investment effect is being concealed by a negative selection effect. Thus it appears that low intangible investment is a not a likely candidate for a large contribution to New Zealand's relatively poor productivity performance.

Instead, such investment appears to be associated with firm growth, and possibly improvement in firm performance along dimensions that are not captured by productivity statistics. The results do not allow us to say whether intangible investment causes firm growth, in the sense of being a choice available to any firm that wants to grow faster. But it is clearly associated with growth, which suggests that in at least some situations it is a necessary factor for growth.

\section{Literature}

Much of the previous literature on intangibles and firm performance focuses specifically on research and development (R\&D). F. M. Scherer was a pioneer of this literature. Scherer (1982) is one of the earliest studies to document the empirical linkage between expenditure on $R \& D$ and productivity growth. Similarly, Scherer (1983) looks at the contribution of firm R\&D to innovation, as represented by patents. A major theme of Scherer's work has been the 
application of the Schumpeterian perspective to empirical analyses of innovation and firm performance (Scherer, 1986). Its key insight is that innovation is the result of firms' investments, which are in turn driven by the forces of competition, resulting in a process of creative destruction whereby innovators' success simultaneously erodes the market power of previous incumbents and induces the next round of competitors.

Griliches (1979) highlights the difficulties -- both conceptual and empirical -- in studying the impact of R\&D on productivity growth, while Pakes and Griliches (1984) model the flow of intangible R\&D investment into innovation output as measured by patents; they find that their knowledge production function explains much of the between-firm variation in knowledge but little of the within-firm changes over time. Crepon et al. (1998) develop a framework for analysing the determinants of $R \& D$, how $R \& D$ contributes to innovation, and finally how innovation contributes to productivity. Their empirical results are consistent with the typical stylised facts: R\&D increases with firm size, market share, and diversification; innovation output increases with research effort and demand-pull and technology indicators; and firm productivity increases with innovation output, even after controlling for the skill composition of labour.

More recently, researchers have begun to look at intangible investment more broadly, as $R \& D$ is only one facet of intangible investment and is more relevant in some industries than others. Corrado et al. (2005) argue that intangible investment should be treated equivalently to tangible investment; it delays current production in order to increase future production. They group intangible capital into three broad categories that have gained traction in the literature: computerised information (primarily software and databases); innovative property (primarily R\&D); and economic competencies (firm-specific resources, including trained employees, brand names, etc.). While caveating their imperfect data, they estimate that intangible expenditure made up around 13 percent of GDP in the US in the late 1990s, and conclude that the only reason for not incorporating intangibles into the productivity framework should be a lack of 
data. They end with the hope that statistical agencies will work towards the development of accurate intangible measures.

Corrado et al. (2009) build on their 2005 paper by incorporating intangibles into growth accounting, and find that output per hour in the non-farm business sector is $10-20$ percent higher when intangibles are measured. Relatedly, Elnasri and Fox (2015) examine the presence and trends of intangibles in the Australian economy; they find that the ratio of intangible to tangible investment increased from around 0.24 in $1974-75$ to 0.36 in 2012-13.

These studies examine intangible investment at the macro level. Limited recent work has analysed intangibles at the firm level, though firm-level analysis is needed to uncover the determinants and consequences of intangible investment. Crass and Peters (2014) believe that many of the within-industry differences in productivity can be explained by differences in intangible investment. Using survey data on German manufacturing and services firms, they find positive associations between firm productivity and their three measures of intangibles: innovative capital, human capital, and branding capital. Bontempi and Mairesse (2015) use Italian firm-level data and find an output elasticity of overall intangible capital of 0.03-0.07. Furthermore, their data allow them to measure intangible expenditure as an investment, and they argue that accounting standards that treat intangibles as costs tend to underestimate the true impact of intangibles on productivity.

Relatedly, Lin and Lo (2015) use data on a panel of Taiwanese manufacturing firms and their expenditures on intangibles as measured by: the acquisition of technology; purchasing of software and databases; marketing; employee training; and R\&D. They present evidence of a positive impact of intangible investment on productivity, with an overall output elasticity of around 0.07. Finally, Montresor and Vezzani (2016) investigate the links between intangible investment and innovation by examining a cross-section of European firms that appear in a 2013 multi-country survey. They conclude that developing intangibles internally rather than externally is conducive to innovation; that the amount invested is important for firms in manufacturing but not in services; and that investing in 'technological' intangibles (R\&D, 
software and design) fosters innovation more than investing in non-technological intangibles (training, reputation/ branding, and organisational/business processes).

A final strand of literature focuses on whether resources flow freely to firms that will use these resources productively. Balasubramanian and Sivadasan (2011) look at U.S. firms and find that increases in a firm's patent stock is strongly associated with increases in size, while weaker evidence also suggests that patenting is associated with an increase in the number of new products, capital intensity, skill intensity and productivity. Similarly, Andrews et al. (2014) examine firms across 23 OECD countries from 2003-2010 and find that within-firm increases in patenting lead to increases in employment, capital, turnover, and value added. They also use patent litigation data to construct an instrumental variable for the patent stock, and suggest that the increase in real economic activity from patenting is causal. More broadly, Andrews and de Serres (2012) emphasise the importance of reallocating labour and capital to intangiblesinvesting firms, as such investment flourishes when supported by standard tangible investment. They conclude that some countries are more successful at channelling resources to their most productive use, and suggest future research should analyse which policies are conducive to targeting resources to intangibles-investing firms.

Our study adds to this literature by examining the links between broad intangible investment and activity across all industries in New Zealand. The use of numerous indicators allows us to consider the numerous types of intangible investment -- including R\&D, employee training, and organisational restructuring -- while the rich firm-level data allow us to describe in detail the characteristics of firms that invest in intangibles, and what happens to them subsequently.

\section{$3 \quad$ Data}

\subsection{Description of data and key variables}

We use data from Statistics New Zealand's Longitudinal Business Database (LBD): a firm-level longitudinal dataset that contains administrative and survey data. Within the LBD, our main 
sample consists of firms that appear in at least one innovation module of the Business

Operations Survey (BOS). The BOS is an annual survey of business performance and activities that is explicitly designed for longitudinal analysis (Fabling \& Sanderson, 2016); however, our key intangible measures come from the innovation module, which appears every second year (2005, 2007, 2009, 2011 and 2013). For firms that make at least one appearance in the innovation module, we then link administrative data from the given and additional years to create an unbalanced panel of firms that covers odd years in the period 2005-2013. This broad sample contains 12,603 firms and 52,983 firm-years, with the average firm's appearing 4.2 times.

The following question contains our main measure of intangible investment: ${ }^{2}$

During the last 2 financial years, did this business do any of the following? (Mark

whether done to support innovation; ${ }^{3}$ done though not to support innovation; not applicable; or don't know)

- Acquisition of computer hardware and software

- Implementing new business strategies or management techniques

- Organisational restructuring

- Design (e.g. industrial, graphic or fashion design)

- Market research

- Significant changes to marketing strategies

- Employee training

- Any research and development in the previous year ${ }^{4}$

\footnotetext{
2 The batch of questions also asks about acquiring of machinery and equipment; acquiring of other knowledge (e.g., licenses, patents, or other intellectual property); and marketing the introduction of new goods or services. We exclude the first as it is a measure of tangible investment, and exclude the latter two as firms may see them as innovation-output indicators, rather than measures of intangible investment.

${ }^{3}$ In 2005 the question only asks whether the activities were done to support innovation, meaning there is a systematic difference in our intangible measures between 2005 and the other years. Including year fixed effects in our later regression analysis helps to deal with this issue.

4 This question comes from the main 'business operations' module, and so asks whether R\&D occurred in the previous year rather than in the previous two years. The question does not ask whether it is done to support innovation, though presumably fostering innovation is an inherent goal of R\&D.
} 
From these indicators, our main measure of firm-level intangible investment is a simple intangibles index, which ranges in value from zero to one and is defined as:

$$
\text { intangibles index }=\frac{\text { no. of intangible activities engaged in }}{\text { no. of nonmissing intangible indicators }}
$$

Hence we give equal weight to each intangible indicator, lacking strong theory on the different contributions of different types of intangible investment. Scaling by the number of non-missing intangible indicators ensures we don't infer that a firm has low intangible investment simply because it failed to answer a question, though we set the index to missing when a firm is missing four or more of the eight indicators. ${ }^{5}$ As an alternative, we perform principal component analysis on these eight indicators. Principal components analysis is a datadriven method for taking a large number of variables that are believed to capture overlapping aspects of the same phenomena, and reducing them to a smaller number of variables that capture most of the information present in the larger variable set. This reduces the eight responses to two constructed 'component' variables designed to capture the patterns of the eight original metrics. The correlation matrix of the intangibles indicators is presented in Appendix Table 1, while the weights of each indicator for the two components are shown in Appendix Table 2.6

A separate measure of intangible investment comes from the following question on intangibles-related expenditure ${ }^{7}$ :

\section{For the last financial year, please estimate this business's combined expenditure on (the}

\section{following) product development and related activities:}

- Research and development

- Design

\footnotetext{
${ }^{5}$ We assume the information in these answers is too messy and better dropped. This sets $12 \%$ of index values to be missing, though the majority (72\%) of these changes come from the $2005 \mathrm{BOS}$, where non-innovating firms were steered away from the question on intangible investments.

${ }^{6}$ In practice we only use the primary principal component, but present details on the second component for completion. In addition we use tetrachoric correlations between the underlying indicators, which estimate the correlation between two indicator variables, assuming that some normally-distributed latent variable underlies them.

7 This question was not asked in 2005; our expenditure measures are missing for this year.
} 
- Marketing and market research (for product development)

- Other expenditure related to product development (e.g. prototyping, trials, commercialisation)

In parts of our analysis we use these questions as another measure of a firm's intangible investment, either by summing the total expenditure on these activities, or by using a dummy variable for whether a firm reports any expenditure.

In our analysis of firm-reported customer and employee satisfaction, we use the following questions from the main 'business operations' module: ${ }^{8}$

\section{Is this business lower than competitors; on a par with competitors; higher than competitors; or don't know for the each of the following?}

- Costs

- Time taken to provide customers with goods or services

- Quality

- Flexibility or ability to make changes

- Customer satisfaction

- Employee satisfaction

We use the answers for customer and employee satisfaction as indicators of some kind of firm 'success." We use the other answers to try to control for a generic tendency of the questionnaire respondent towards self-congratulation or overconfidence regarding the firm's overall quality or performance. We construct a simple 'confidence' index as the average reported category for questions on relative costs; relative time to provide goods and services; relative quality of goods and services; and relative flexibility. We assign the number 1 to "lower" answers, 2 to "on par" answers, and 3 to "higher than" answers. Hence the confidence index takes on values between 1 and 3, where a value of 3 corresponds to answering "higher than" on all of our control questions.

\footnotetext{
8 The question is slightly rephrased for clarity, but the substance and key words are unchanged.
} 
We combine these self-reported answers with administrative data from the LBD that show other firm characteristics and allow us to compute measures of firm performance. Firm size in a given year is measured by average monthly full-time equivalent (FTE) labour, using the FTE measure that was created by Fabling and Maré (2015b). Firm age is derived from the birth date of the firm, while a firm's time-invariant industry comes from Australian and New Zealand Standard Industrial Classification (ANZSIC) 2006 codes. At the broadest level there are 19 industry divisions, as listed in Appendix Table 3, though for much of our analysis we use the more detailed level 3 ANZSIC 2006 codes, which divide firms into 203 disaggregated industries.

Finally, productivity data comes from the work of Fabling and Maré (2015a). Their created dataset includes measures of gross output (deflated revenue); capital (deflated flow of capital services in a year); labour (using their adjusted FTE measure); and deflated intermediate consumption. These measures allow us to examine what happens to firms' inputs and outputs after investing in intangibles, and also allow us to measure labour productivity as the ratio of value added to labour input. We also measure profitability as profit (value added minus total wages) per unit of capital. Finally, multi-factor productivity (MFP) is measured by the residuals in the Fabling and Maré (2015a) dataset, which come from translog gross-output production function regressions that are run separately for 52 industries. Hence these MFP measures are derived from the entire population of firms with available production data, and not only our sample of firms. This gives a more accurate picture of a firm's productivity relative to the industry average. ${ }^{9}$

Our sample size decreases in analysis that require these productivity data, from 12,603 firms that provide 52,983 observations to 9,756 firms that provide 28,236 observations. Partly this is because certain firms don't meet the criteria or have implausible variation in inputs/outputs (see Fabling and Maré 2015a for details). Also, productivity data are not yet available for the 2013 March-year, which causes the loss of 9,936 observations.

\footnotetext{
${ }^{9}$ We also use the alternate firm identifiers developed in Fabling (2011) to fix broken firm identifiers.
} 


\subsection{Descriptive Statistics}

Table 1 shows the proportion of firm-year observations that report engaging in various intangible activities, across the entire period. At the high end, over 70 percent of firm-years report acquiring computer-ware and training employees, while the least common activities are significant changes to marketing strategies (22 percent), design (20 percent), and R\&D (12 percent).

Table 1: Proportion of firm-years engaging in intangible activity

\begin{tabular}{lcc}
\hline \hline Intangible activity & $\begin{array}{c}\text { Proportion of } \\
\text { firm-years }\end{array}$ & $\begin{array}{c}\text { Number of } \\
\text { firm-years }\end{array}$ \\
\hline $\begin{array}{l}\text { Acquisition of computer hardware \& software } \\
\text { Implementing new business strategies/management }\end{array}$ & 0.723 & 27,354 \\
techniques & 0.429 & 27,300 \\
Organisational restructuring & 0.413 & 27,315 \\
Design & 0.196 & 27,375 \\
Market research & 0.281 & 27,384 \\
Significant changes to marketing strategies & 0.218 & 27,375 \\
Employee training & 0.787 & 27,441 \\
Research and development & 0.123 & 30,804 \\
Any intangible expenditure & 0.327 & 23,142
\end{tabular}

Notes: Statistics are for the period (odd years) from March-year 2005 to March-year 2013. The first seven dummies measure whether the firm reports engaging in the activity in the previous two years, while the latter two are for the previous year, as outlined in the data section. The reported numbers of observations have been randomly rounded to the nearest multiple of 3, as required by Statistics NZ confidentiality rules.

To provide more detail, Figure 1 presents, separately for each level 1 industry, the proportion of firm-years engaging in each of the eight intangible activities. The figure shows many similarities across industries. For example, in each industry the percentage of firm-years investing in employee training is greater than 70 percent, while the percentage reporting R\&D is less than 30 percent. The differences that do exist are expected, and lend credibility to the intangible indicators as capturing real activities. Professional services firms have a relatively high likelihood of investment in all forms of intangibles, and agriculture firms relatively low. 
Manufacturing is the only industry with more than 20 percent of firms reporting R\&D; the percentage doing restructuring is $10-20$ percentage points lower in agriculture and mining than in most other industries; and investment in computer-ware is most prevalent in information media, administration/support services and public administration.

Figure 1: Proportion of firm-years engaging in each intangible activity, by industry

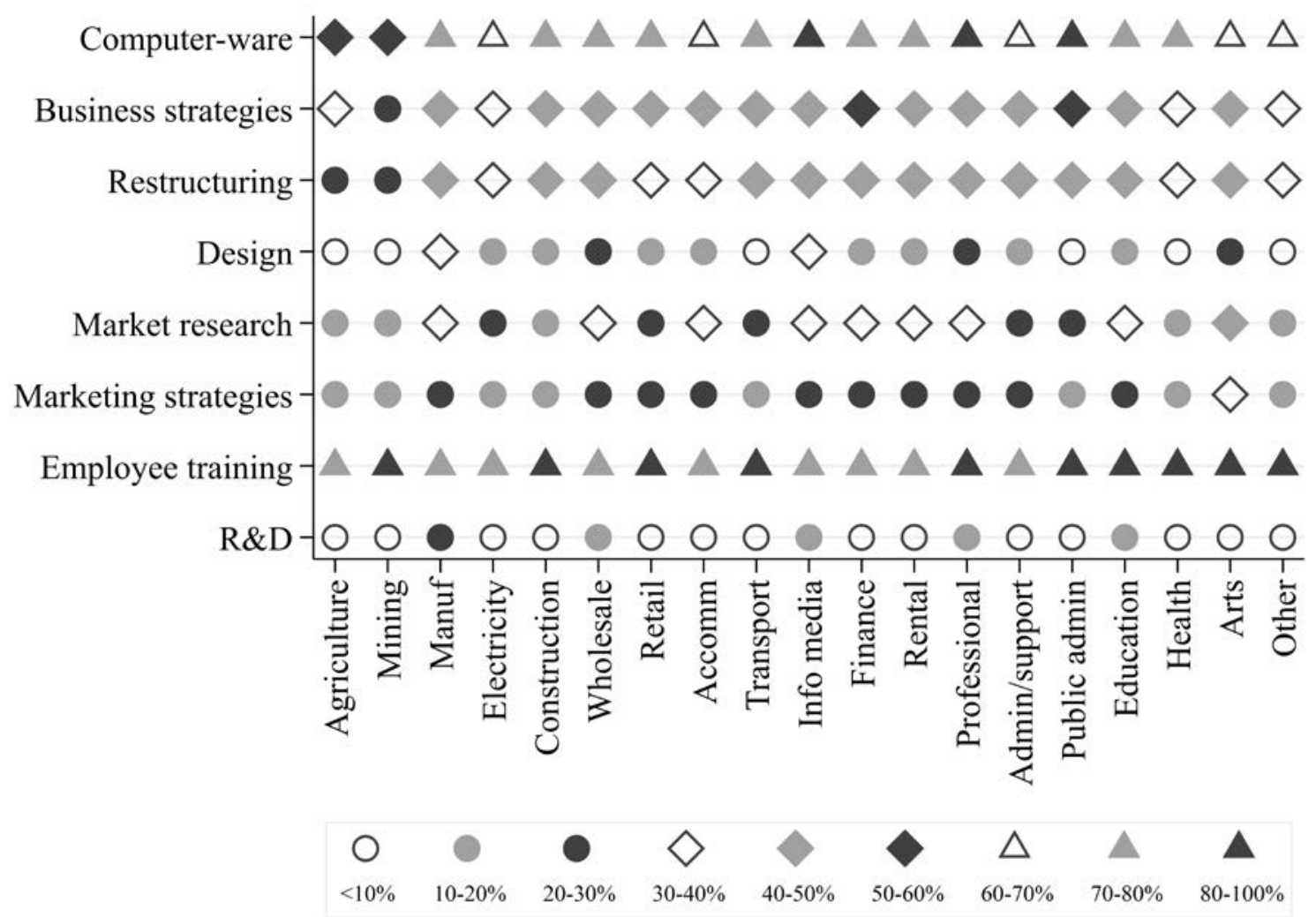

Notes: Full intangible activity descriptions are given in Section 3.1. Full industry descriptions are given in Appendix Table 3.

Table 2 summarises the transitions into and out of intangible investment for firm-years in our sample. For a firm that was also in the innovation module two years previously, we report whether it adopted an intangible activity; dropped an intangible activity; or has the same status as last time (either doing the activity in both periods, or in neither period). There is some evidence of dynamism here: For most intangible indicators, between nine and 17 percent of firm-years report picking up an activity in which they were not engaged two years ago, with similar but slightly higher proportions for dropping an activity. 
Table 2: Proportion of firm-years transitioning into and out of intangibles

\begin{tabular}{|c|c|c|c|c|c|}
\hline \multirow{2}{*}{ Intangible activity } & \multirow{2}{*}{$\begin{array}{c}\text { Adopted } \\
{[0 \rightarrow 1]}\end{array}$} & \multirow{2}{*}{$\begin{array}{c}\text { Dropped } \\
{[1 \rightarrow 0]}\end{array}$} & \multicolumn{2}{|c|}{ Unchanged } & \multirow{2}{*}{$\begin{array}{l}\text { Number of } \\
\text { firm-years }\end{array}$} \\
\hline & & & {$[1 \rightarrow 1]$} & {$[0 \rightarrow 0]$} & \\
\hline New computer-ware & 0.136 & 0.152 & 0.598 & 0.114 & 14,421 \\
\hline New business strategies & 0.156 & 0.194 & 0.248 & 0.402 & 14,376 \\
\hline Organisational restructuring & 0.167 & 0.187 & 0.235 & 0.411 & 14,391 \\
\hline Design & 0.091 & 0.109 & 0.096 & 0.704 & 14,502 \\
\hline Market research & 0.119 & 0.142 & 0.156 & 0.583 & 14,496 \\
\hline Changes to mkting strategies & 0.119 & 0.136 & 0.085 & 0.660 & 14,496 \\
\hline Employee training & 0.105 & 0.125 & 0.693 & 0.077 & 14,556 \\
\hline Research and development & 0.058 & 0.054 & 0.078 & 0.810 & 16,767 \\
\hline Any intangible expenditure & 0.110 & 0.114 & 0.208 & 0.537 & 12,219 \\
\hline
\end{tabular}

Notes: Statistics are for the entire period (odd years) from March-year 2005 to March-year 2013. The first seven dummy variables measure whether the firm reports engaging in the activity in the previous two years, while the latter two are for the previous year, as outlined in the data section. The reported numbers of firm-years have been randomly rounded to the nearest multiple of 3 , as required by Statistics NZ confidentiality rules.

Table 3 summarises the distribution of the non-binary intangible measures, where the intangibles index is constructed from the eight dummy variables as described in Section 3.1. The intangibles index distribution is fairly symmetric, with the mean close to the median. The median value of 0.375 corresponds to engaging in three intangible activities for a firm with no missing dummy variables $\left(0.375^{*} 8=3\right)$. It is striking that, in contrast, the majority of firms do not report spending any money on the categories for product development and related activities: The median value of total intangible expenditure, and hence all the component categories, is $\$ 0$. Even the $90^{\text {th }}$ percentile value is fairly low, with a value of $\$ 150,200$ for total intangible expenditure and between $\$ 3,000$ and $\$ 20,000$ for the component categories, though these values steeply increase when we observe the $95^{\text {th }}$ percentile value.

How do we reconcile the fact that most firms say they engage in these activities, and yet a majority do not report any expenditure? One explanation is that firms may falsely report engaging in broadly defined activities that are viewed positively (e.g. employee training or 
market research), but tell the truth when it comes to the specifics of how much was spent.

Alternatively, a firm may well know that it had activities that fit a given intangible definition, but not track expenditures that are connected to those activities. Hence in our analysis we focus on the broad intangible indicators and the construced intangibles index, but use reported expenditure in robustness tests as an alternative measure of intangible investment.

Table 3: Distribution of self-reported intangible investment, all years

\begin{tabular}{|c|c|c|c|c|c|c|}
\hline Statistic & $\begin{array}{l}\text { Intangibles } \\
\text { index (0-1) }\end{array}$ & $\begin{array}{c}\text { Total } \\
\text { intangibles } \\
\text { expenditure }\end{array}$ & $\begin{array}{c}\text { R\&D } \\
\text { expenditure }\end{array}$ & $\begin{array}{c}\text { Design } \\
\text { expenditure }\end{array}$ & $\begin{array}{c}\text { Marketing } \\
\text { expenditure }\end{array}$ & $\begin{array}{c}\text { Other } \\
\text { expenditure }\end{array}$ \\
\hline mean & 0.397 & $\$ 191,400$ & $\$ 105,000$ & $\$ 18,300$ & $\$ 52,200$ & $\$ 22,700$ \\
\hline 10th pctile & 0.125 & 0 & 0 & 0 & 0 & 0 \\
\hline 25th pctile & 0.25 & 0 & 0 & 0 & 0 & 0 \\
\hline median & 0.375 & 0 & 0 & 0 & 0 & 0 \\
\hline 75th pctile & 0.6 & $\$ 10,000$ & 0 & 0 & 0 & 0 \\
\hline 90th pctile & 0.75 & $\$ 150,200$ & $\$ 18,000$ & $\$ 3,000$ & $\$ 20,000$ & $\$ 5,000$ \\
\hline 95th pctile & 0.875 & $\$ 497,000$ & $\$ 162,300$ & $\$ 20,000$ & $\$ 98,600$ & $\$ 30,000$ \\
\hline $\begin{array}{l}\text { Number of } \\
\text { firm-years }\end{array}$ & 27,396 & 23,142 & 22,236 & 22,224 & 22,209 & 22,215 \\
\hline
\end{tabular}

Notes: Statistics are for the entire period (odd years), from March-year 2005 to March-year 2013. The reported numbers of firm-years have been randomly rounded to the nearest multiple of 3, as required by Statistics NZ confidentiality rules.

Figure 2 plots the average and one-standard-deviation spread of the intangibles index across all firm-years in the data, separately for each level 1 industry. The results show plausible variation in intangible investment across industries; firms in 'information media', 'manufacturing', or 'professional, technical and scientific services' have an average index value of over 0.4 , which corresponds to just over three out of eight activities when all questions are answered. In contrast, the average index for firms in 'agriculture' or 'mining' is around 0.3 , which corresponds to around two of the eight activities. The bands show all values that fall within one standard deviation of the mean for each industry, and show substantial variation in 
intangible investment for each industry. Indeed, a firm that is one standard deviation above the mean for the lowest average industry (agriculture) participates in more intangible investment categories than the average firm in the highest average industry (information media). Appendix Figure 1 plots the average principal component and one-standard-deviation bands by industry, and reveals a similar pattern.

A particular concern with the intangibles survey questions might be that with respect to any question of the form "did your firm do any of this activity", larger firms are more likely to answer yes because the chances of any activity occuring somewhere in the firm are higher for a larger firm. To explore this issue, Appendix Table 4 presents a regression of firms' intangible investment on past firm size and industry dummies. The differences across industries remain. Together with Figure 1, these show that the BOS intangibles data are consistent with broad pre-existing notions of where such activity is likely. However, the large standard deviation bands show that the variation in firms' index values within an industry dominates the variation across industries.

Figure 2: Mean and spread of intangible investment, by industry

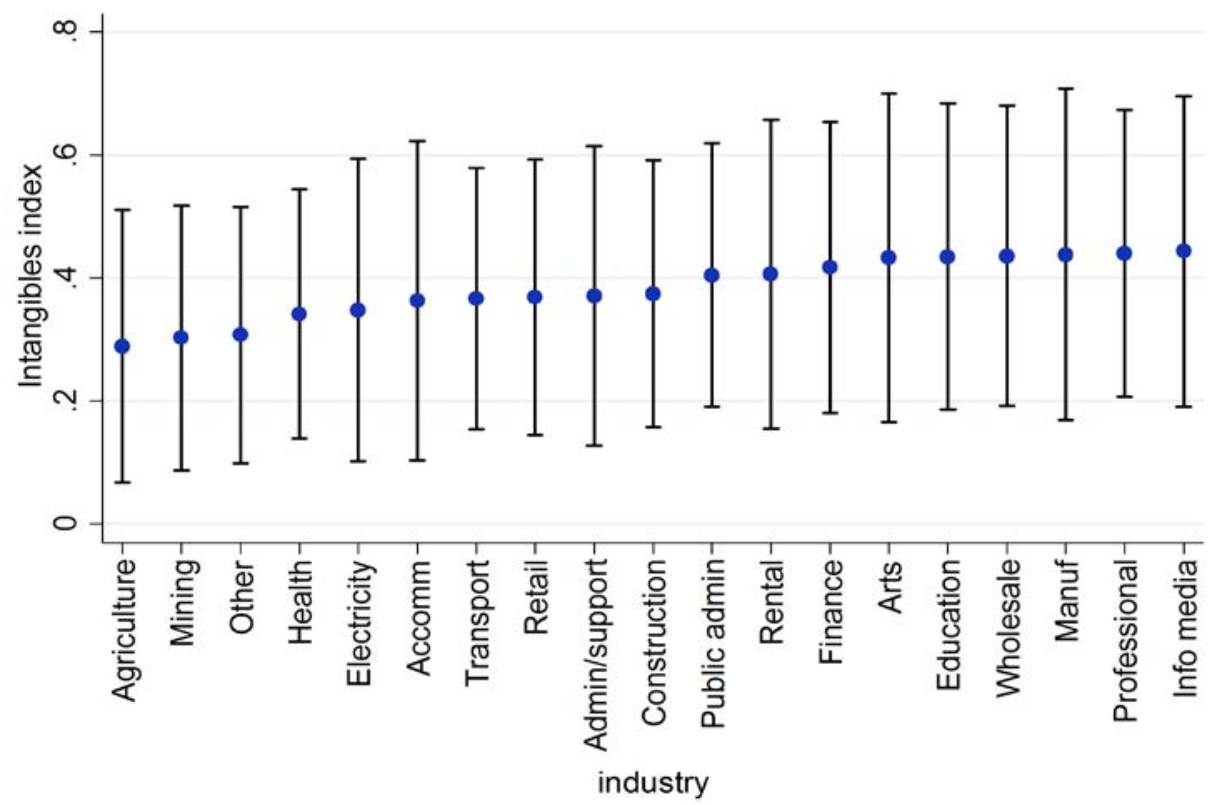

Notes: Figure 2 presents, as dots, the mean intangibles index for all firm-years by industry over the period 2005-2013. The bands show all values that fall within one standard deviation of the mean for each industry. Full industry descriptions are given in Appendix Table 3. 
Figure 3 explores the variation in the intangibles index within firms. It shows the cumulative distribution function (CDF) of the ratio of each firm's minimum intangibles index to its average intangibles index, in panel $\mathrm{A}$, and the ratio of the maximum intangibles index to the average, in panel B. The CDF shows the proportion of firms that take a given value or lower, with the proportion ranging from $0-1$ on the vertical axis. For example, panel A shows that only about half of the firms experience a year in which the index is less than $60 \%$ of its average value for that firm. Approximately 90 percent of firms experience a year in which the index is $90 \%$ of its average value or lower. Panel B shows that for about a quarter of the firms, the maximum value that is experienced by that firm is no more than $20 \%$ greater than the average, while about 85 percent of firms have a maximum ratio of 2 or less. ${ }^{10}$

We interpret Figure 3 as showing a plausible degree of variation. We see neither a large number of firms with no variation over time, nor a large number with dramatic variations from year to year.

\section{$4 \quad$ Results}

\subsection{Explaining intangible investment}

Our first set of regressions describe the characteristics of firms that invest in intangibles. ${ }^{11} \mathrm{We}$ estimate the following reduced-form model:

$$
\text { investment }_{j k t}=\beta_{0}+\beta_{1} X_{j k t-1}+\rho_{k t}+\varepsilon_{j k t}
$$

where $j$ denotes firm, $k$ denotes industry, and $t$ denotes year. $X_{j k t-1}$ is a vector of last-period firm characteristics, which include: FTE; self-reported competition; age; and output growth relative to the industry average. The $\rho_{k t}$ represent a complete set of year-industry interacted fixed effects, which thus allow each industry to have its own average investment rate and its

\footnotetext{
10 The large ratio values of three and above in panel B are driven by firms with very low average index values, which blow up the proportion when used as the denominator.

11 Appendix Table 5 presents summary statistics of variables appearing in any of the regression tables in this paper.
} 
Figure 3: Variation in the intangibles index within firms

Panel A: CDF of minimum intangibles index as proportion of the average

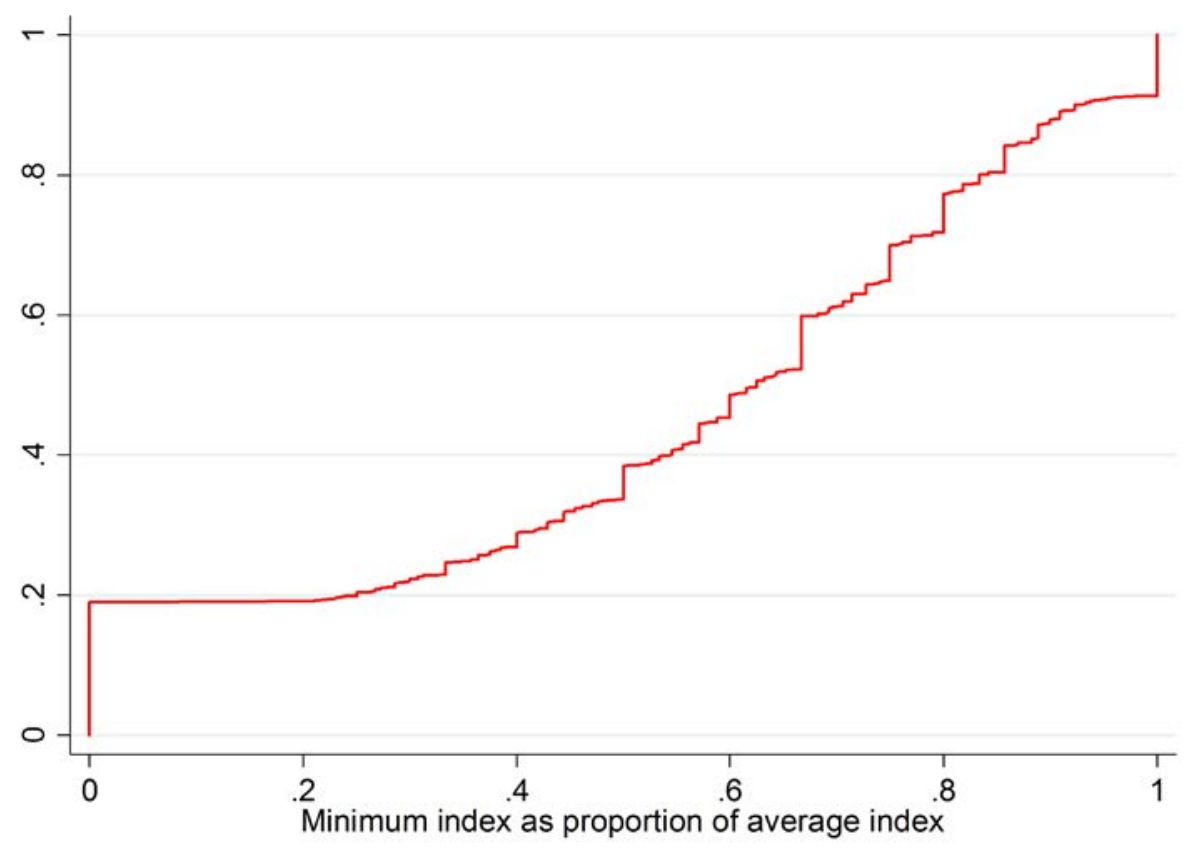

Panel B: CDF of maximum intangibles index as proportion of the average

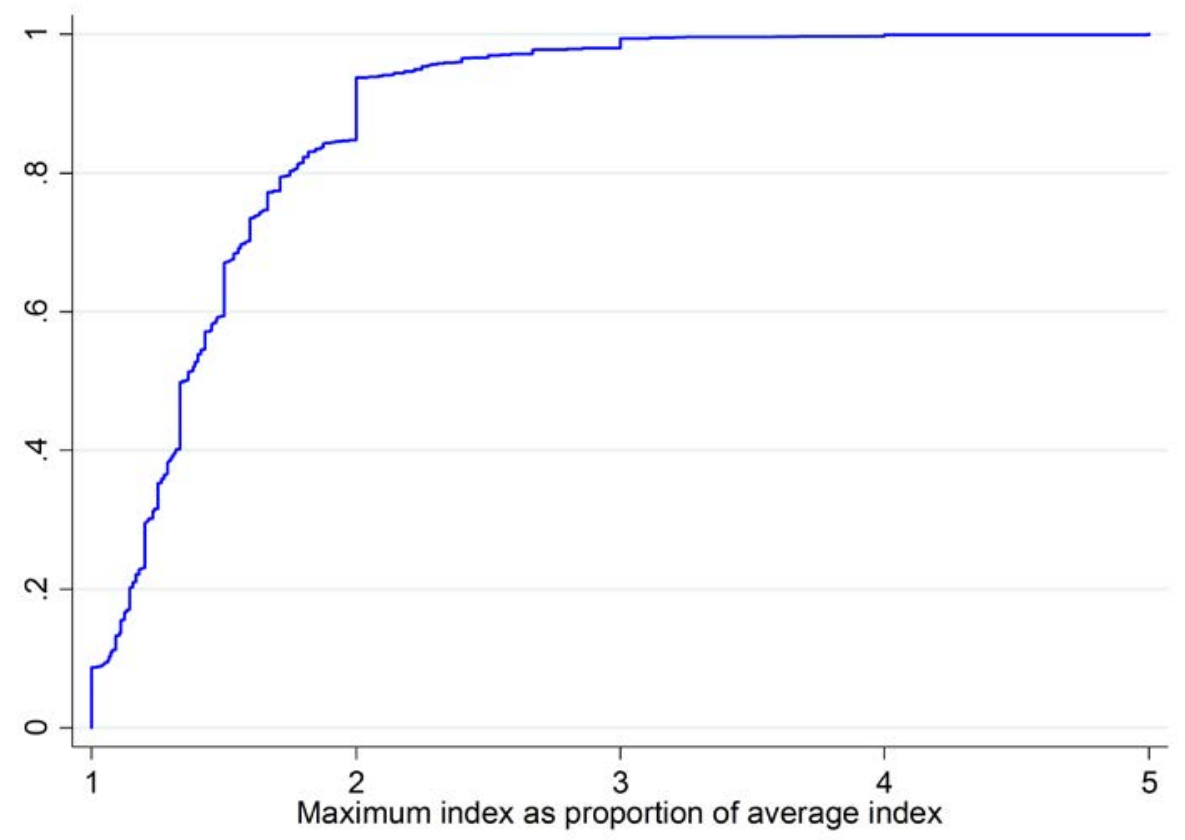

Notes: Figure 3 presents cumulative distribution functions of the minimum and maximum ratio of the intangibles index in a given year to the firm's average intangibles index across all years. The sample is limited to firms that appear at least twice.

own common time trend. In alternative specifications, we replace the industry and industrytime fixed effects with firm fixed effects (retaining only an aggregate set of year effects), and 
thus examine within-firm variation in the covariates and how this translates to subsequent intangible investment.

Note that our industry classification is considerably disaggregated, using level 3 ANZSIC 2006 codes, which divide firms into 203 industries. Firm characteristics are lagged because of the nature of our intangible measures: As was detailed in Section 3.1, firms report intangible activity over the past two years (or one year for the R\&D indicator and expenditure measures), and we do not want to explain past intangible investment using current firm characteristics. We cluster standard errors at the firm level to account for within-firm correlations of the error term over time.

Table 4 presents ordinary least squares (OLS) regressions ${ }^{12}$, where the intangibles measure is a firm's intangibles index in columns (1) to (3) and an indicator for the firm reporting any intangible expenditure in columns (4) to (6). In columns with age-category dummy variables, the omitted age category is between six and ten years old, and so all agecategory coefficients are interpreted relative to this baseline. Similarly, the omitted category for self-reported competition is many competitors, some dominant, so competition coefficients are interpreted relative to this monopolistic-competition baseline.

Column (1) shows our baseline specification, and indicates that firm size is associated with a small but statistically significant increase in the intangibles index. The coefficient of 0.057 implies that a doubling of firm size is associated with an increase of just under half an intangible investment activity for firms with no missing intangible indicators. We also see that younger firms tend to invest more; for example, the intangibles index is 0.029 greater for firms that are aged less than two years relative to firms that are aged 6-10 years.

There is also evidence of some relationship between intangibles and competition, reminiscent of findings of such a relationship between innovation and competition (e.g. Aghion

\footnotetext{
12 Average marginal effects are very similar when estimating fractional logit models in columns (1)-(2) and logit models in columns (4)-(6). We show OLS results because of the ease of interpretation and because the estimator is tractable enough to include industry-year interactions.
} 
et al., 2002). In particular, the estimates indicate that firms that perceive themselves to be operating in a 'captive market' engage in just under half an intangible investment less than firms with 'many competitors, some dominant.' But there is some evidence of an inverted U-shaped relationship, with intangible investment decreasing slightly for firms reporting the highest perceived competition, relative to the intermediate, baseline group.

Column (2) keeps the same controls but includes a firm's output growth four to two years ago relative to its industry average, in decimal form. This investigates whether firms that invest in intangibles are building on success or, alternatively, responding to perceived weakness in competitive performance. The coefficient estimate of 0.020 is positive and statistically significant, but is economically insignificant: A firm whose recent growth exceeded the industry average by 10 percentage points would be predicted to have an increase in the intangibles index of about $.002(0.1 \mathrm{x} .02)$. This indicates that intangibles-investing firms were neither thriving nor struggling prior to investment, but rather had similar momentum to other firms in their industry.

Column (3) includes firm fixed effects, so that only within-firm variation in the other explanatory variables explains intangible investment. We control for the log of age instead of age-category dummies, because few firms make the discrete jump from one category to the other, and we would not expect large effects from crossing the thresholds.

Unsurprisingly, the results become much noisier, with most estimates losing statistical significance. This means that the results in Column (1) with regard to (for example) firm age are not driven by the firms in the sample decreasing their investment as they age. Rather, the results are driven by the cross-sectional variation: a tendency for younger (or larger) sample firms to be bigger investors, all else equal, than the older (or smaller) ones. The diminished but still positive relationship between intangible investment and firm size means that in addition to the cross-sectional relationship, there is some tendency for firms' investment to increase/decrease as they grow/shrink over the sample period; however, this result is not statistically significant. 
Columns (4) to (6) of Table 4 mirror the first three columns, but replace the dependent variable with an indicator for reporting any intangible expenditure. A similar picture emerges. In column (4) we see that intangible investment is associated positively with firm size and negatively with age, though these estimates are statistically insignificant. In terms of competition we again see a negative effect of 'captive market' and a smaller negative effect of 'many competitors, none dominant', in both cases relative to the intermediate 'many competitors, some dominant'. Column (5) shows that firms that report any intangible expenditure experienced similar output growth to the industry average, holding all else constant; a firm whose recent growth exceeded the industry average by 10 percentage points would be expected to have an economically tiny 0.25 percentage point higher chance of reporting any intangible expenditure $(\exp (0.1 \mathrm{x} 0.025)-1)$.

The firm-fixed-effects results in column (6) show point estimates that are small in magnitude and statistically insignificant. The relatively large standard errors cloud any lessons that can be learnt from this specification.

Finally, we note that we have included in all of these regressions a dummy variable for those firms that responded "don't know" to the competition question, and this group shows generally lower intangible investment, all else equal. We suspect that this reflects that such firms simply did a poorer job overall in responding to the survey, but there is no way really to know.

As further robustness explorations, Appendix Table 6 replicates Table 4 with the principal component summary of the multiple intangibles questions rather than our constructed index, and the log of reported expenditure rather than the simple yes/no indicator for expenditure. The results are qualitatively similar.

\subsection{Firm performance and past intangible investment}

The next set of regressions address firm performance outcomes after intangible investment, with versions of the following baseline model run at the firm-year level: 


$$
y_{j k t}=\beta_{0}+\beta_{1} \text { intangibles }_{j k t-1}+\beta_{2} \text { age }_{j k t}+\beta_{3} \text { competition }_{j k t}+\rho_{k t}+\varepsilon_{j k t},
$$

where $j$ denotes firm, $k$ denotes industry, and $t$ denotes year, and $y_{j k t}$ is a measure of firm performance, such as multi-factor productivity, labour productivity, or profitability. As before, we include a complete set of industry-year interactions. We also include a 'doesn't-know' intangibles index, which is constructed in the same way as our intangibles index but for the number of 'don't know' answers for a firm. Hence the intangibles index is interpreted relative to the proportion of indicators not engaged in, holding constant the 'doesn't-know' answers.

In principle, what should affect performance is the stock of intangible capital. Our intangibles indicator is more closely related to the flow of intangible investment than to the stock, although across firms the stocks and flows are typically highly correlated. If productivity depends on the stock, then the change in productivity from one year to the next is approximately related to the flow. Given the ambiguity of the meaning of our intangibles indicator, rather than pick a single form for this relationship, we explore a number of different variations.

Clearly the decision to invest in intangibles is endogenous: Firms decide whether and when to invest. If the factors that affect that decision are correlated with the $\varepsilon_{j k t}$ in Eq. (2), then our estimates of $\beta_{1}$ will be biased. While the theoretically possible ways that this might occur are almost limitless, two are of particular concern in this context: First, there may be unobserved firm attributes or developments in the firm's environment that affect both its incentive to invest in intangibles and its productivity. For example, if the firm hires a new hot-shot manager, she may increase intangible investment, and she may also directly increase productivity. In that case, it will appear as if intangible investment is increasing productivity -- even if it doesn't. This possibility, if present, leads to an upward bias in the estimate of $\beta_{1}$. 
Table 4: Characteristics of intangibles-investing firms

\begin{tabular}{|c|c|c|c|c|c|c|}
\hline Dependent variable: & $\begin{array}{l}\text { Intangibles } \\
\text { index (0-1) }\end{array}$ & $\begin{array}{l}\text { Intangibles } \\
\text { index (0-1) }\end{array}$ & $\begin{array}{l}\text { Intangibles } \\
\text { index (0-1) }\end{array}$ & $\begin{array}{l}\text { Any intangible } \\
\text { expenditure }\end{array}$ & $\begin{array}{l}\text { Any intangible } \\
\text { expenditure }\end{array}$ & $\begin{array}{l}\text { Any intangible } \\
\text { expenditure }\end{array}$ \\
\hline Full time equivalent (ln) (2-yr lagged) & $\begin{array}{c}0.057^{* * *} \\
(0.002)\end{array}$ & $\begin{array}{c}0.062^{* * *} \\
(0.003)\end{array}$ & $\begin{array}{c}0.010 \\
(0.009)\end{array}$ & $\begin{array}{c}0.046^{* * *} \\
(0.003)\end{array}$ & $\begin{array}{c}0.051^{* * *} \\
(0.004)\end{array}$ & $\begin{array}{l}-0.017 \\
(0.018)\end{array}$ \\
\hline Output growth 4-2 yrs ago relative to industry & & $\begin{array}{c}0.020^{* * *} \\
(0.006)\end{array}$ & & & $\begin{array}{l}0.025^{* *} \\
(0.010)\end{array}$ & \\
\hline Age $<2$ (2-yr lagged) & $\begin{array}{l}0.029^{* *} \\
(0.011)\end{array}$ & $\begin{array}{c}0.032 \\
(0.027)\end{array}$ & & $\begin{array}{l}0.034^{*} \\
(0.021)\end{array}$ & $\begin{array}{l}0.086^{*} \\
(0.051)\end{array}$ & \\
\hline Age 2-5 (2-yr lagged) & $\begin{array}{l}0.011^{* *} \\
(0.006)\end{array}$ & $\begin{array}{l}0.014^{*} \\
(0.008)\end{array}$ & & $\begin{array}{c}0.005 \\
(0.011)\end{array}$ & $\begin{array}{c}-0.019 \\
(0.015)\end{array}$ & \\
\hline Age 11-20 (2-yr lagged) & $\begin{array}{l}-0.011^{* * *} \\
(0.006)\end{array}$ & $\begin{array}{l}-0.011 \\
(0.007)\end{array}$ & & $\begin{array}{l}-0.008 \\
(0.009)\end{array}$ & $\begin{array}{l}-0.018 \\
(0.015)\end{array}$ & \\
\hline Age $21+(2-y r$ lagged $)$ & $\begin{array}{l}-0.005 \\
(0.006)\end{array}$ & $\begin{array}{c}0.003 \\
(0.008)\end{array}$ & & $\begin{array}{l}-0.000 \\
(0.010)\end{array}$ & $\begin{array}{c}-0.008 \\
(0.016)\end{array}$ & \\
\hline Log of age (2-yr lagged) & & & $\begin{array}{c}-0.004 \\
(0.010)\end{array}$ & & & $\begin{array}{c}0.013 \\
(0.021)\end{array}$ \\
\hline Perceived captive market (2-yr lagged) & $\begin{array}{c}-0.052^{* * *} \\
(0.011)\end{array}$ & $\begin{array}{c}-0.041^{* * *} \\
(0.014)\end{array}$ & $\begin{array}{l}-0.010 \\
(0.014)\end{array}$ & $\begin{array}{c}-0.064^{* * *} \\
(0.017)\end{array}$ & $\begin{array}{c}-0.065^{* * *} \\
(0.023)\end{array}$ & $\begin{array}{c}0.004 \\
(0.028)\end{array}$ \\
\hline 1 or 2 competitors (2-yr lagged) & $\begin{array}{l}-0.002 \\
(0.006)\end{array}$ & $\begin{array}{l}-0.006 \\
(0.007)\end{array}$ & $\begin{array}{c}0.009 \\
(0.007)\end{array}$ & $\begin{array}{l}-0.002 \\
(0.010)\end{array}$ & $\begin{array}{l}-0.016 \\
(0.013)\end{array}$ & $\begin{array}{l}-0.015 \\
(0.015)\end{array}$ \\
\hline Many competitors, none dominant (2-yr lagged) & $\begin{array}{c}-0.014^{* * *} \\
(0.005)\end{array}$ & $\begin{array}{l}-0.005 \\
(0.007)\end{array}$ & $\begin{array}{l}-0.002 \\
(0.006)\end{array}$ & $\begin{array}{c}-0.026^{* * *} \\
(0.009)\end{array}$ & $\begin{array}{l}-0.016 \\
(0.012)\end{array}$ & $\begin{array}{l}-0.010 \\
(0.013)\end{array}$ \\
\hline Doesn't know competition (2-yr lagged) & $\begin{array}{c}-0.098^{* * *} \\
(0.012)\end{array}$ & $\begin{array}{c}-0.077^{* * *} \\
(0.016)\end{array}$ & $\begin{array}{c}0.029^{*} \\
(0.015)\end{array}$ & $\begin{array}{c}-0.082 * * * \\
(0.016)\end{array}$ & $\begin{array}{c}-0.097 * * * \\
(0.022)\end{array}$ & $\begin{array}{c}0.008 \\
(0.027)\end{array}$ \\
\hline $\begin{array}{l}\text { Year * level } 3 \text { industry FE } \\
\text { Firm FE }\end{array}$ & Yes & Yes & $\begin{array}{l}\text { Yes } \\
\text { Yes }\end{array}$ & Yes & Yes & $\begin{array}{l}\text { Yes } \\
\text { Yes }\end{array}$ \\
\hline $\begin{array}{l}\text { Observations } \\
\text { Proportion of successes }\end{array}$ & 16,068 & 9,621 & 15,972 & $\begin{array}{c}16,335 \\
0.498\end{array}$ & $\begin{array}{l}9,807 \\
0.519\end{array}$ & $\begin{array}{c}16,035 \\
0.329\end{array}$ \\
\hline R squared & 0.207 & 0.252 & 0.073 & 0.442 & 0.454 & 0.077 \\
\hline
\end{tabular}


Another concern is 'reverse causality': the possibility that productivity (or profitability or another performance measure) has its own effect on intangible investment. If for, example, firms are constrained in their ability to generate the cash that is needed for such investment, then firms with higher productivity—which might well produce higher sales margins-would be more able to engage in intangible investment because the necessary funds are available. This would, again, lead to an upward bias in the estimate. Conversely, as mentioned above, if firms see intangible investment as a way to get themselves out of trouble, then it might be the poorperforming firms that are more likely to undertake it, which would lead to a downward bias.

In most analyses of this kind, the primary concern is that there are unobserved factors that positively affect both the investment and firm performance, which leads to a concern that the effect of investment is over-estimated. As will be seen, we find -- if anything -- negative apparent effects of intangible investment on productivity, which led us to worry more about the possibility of negative reverse causality. However, as we saw above, we find no evidence that prior firm performance is negatively associated with intangible investment, so we do not think that this is driving the results. We will return to consideration of these issues in the final discussion below.

\subsubsection{Multifactor productivity ${ }^{13}$}

Table 5 presents the first set of estimates. The first four columns are in the form of Eq. (2), allowing the firm's MFP to vary with intangible investment, exploring sensitivity to different measures of intangible investment and different data samples. Column (1) measures intangible investment with the intangibles index, and shows a negative relationship between the level of MFP and reported intangible activity two years previous. (Recall that each survey asks about activity over the previous two years, so this regression estimates the effect on MFP of intangible

\footnotetext{
${ }^{13}$ Eq. (2) with MFP as the dependent variable is closely related to a model where the stock of intangible assets is added as a factor of production in the production function (Griliches, 1979). We adopt the approach of first constructing MFP as a residual from the production function, and then regressing this residual on the intangible assets because we have a much larger sample of firms with production data than those for which we have the intangibles data. Thus the other parameters of the production function (e.g. capital and labour elasticities) can be estimated very precisely on this large sample, whereas if we estimated the production function only on the smaller intangibles-data sample the production function would be much less well estimated.
} 
investment 2-4 years earlier.) An increase in the intangibles index corresponding to one more intangible investment out of eight is associated with a decrease in MFP of just under one percentage point (coefficient of about $.064 \times 1 / 8$ ). Since productivity differences among firms are typically on the order of a few percent, this is a meangingfully large effect -- if it is real.

Column (1) also shows the youngest firms have lower MFP, holding all else constant; firms aged 2-5 are on average 5.6 percent less productive than firms aged 6-10. The point estimates for the older age categories are negative, implying older firms are less productive, though these estimates are statistically insignificant. We also see weak evidence of an advantage for self-reported monopolists, though the estimate is also statistically insignifcant. While it is possible that monopolists are truly more productive, if their measured productivity is really higher it is more likely that monopolists have higher price-cost margins, which increases revenue (deflated with an industry-based price index) and hence measured productivity (Maré, 2016).

In column (2) we limit the sample to firms that were in the lower quartile of output in their level 3 industry in 2004. The motivation is that yes/no survey questions may be less meaningful for larger firms, because a large firm is intrinsically more likely to have engaged in a given activity somewhere across the enterprise. Hence limiting the sample to small firms tests whether focusing on a context where the measures are, arguably, more meaningful shows a different picture. ${ }^{14}$ We see no qualitative change in the results.

Columns (3) and (4) of Table 5 vary the measure of intangible investment employed. Column (3) is based on the dichotomous measure of whether any expenditure on intangibles is reported, and Column (4) the log of intangible expenditure for firms with positive reported expenditure. Again MFP's negative association with intangibles remains, though it is not statistically significant.

\footnotetext{
${ }^{14}$ We also ran output-weighted regressions to estimate the association for the average unit of output, rather than the average firm. The results do not change qualitatively.
} 
Table 5: Firm performance and past intangible investment: multifactor productivity

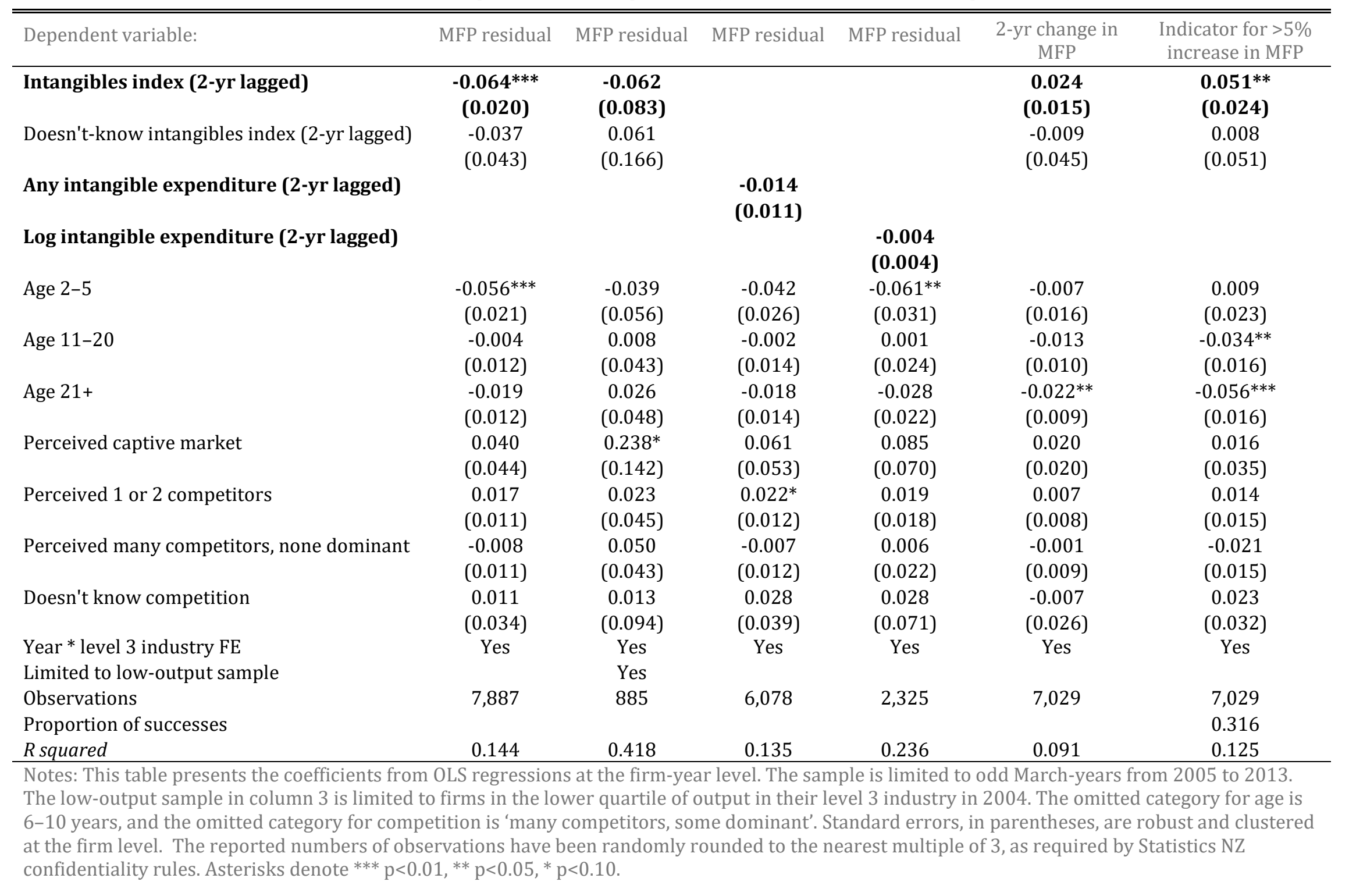


As emphasized by Bontempi and Mairesse (2015), firm productivity should really be related to the stock of accumulated (though depreciated) intangible investment, rather than to the investment flow. This formulation is approximately equivalent to the flow's being related to the change in firm productivity, and our intangible indicator variable is presumably most closely related to the flow because it asks about investment in the last 2 years. This approach is implemented in column (5), with a point estimate that is positive but statistically insignificant and economically modest; engaging in one more intangible activity is associated with a 0.3 percentage point increase in MFP from two years ago (0.024 x 1/8).

Finally, the dependent variable in column (6) is an indicator for MFP's increasing by more than five percentage points. This is intended to look for the 'lottery ticket' view of intangible investment, whereby for most firms it has no effect but for a small number of (lucky?) firms it gives a big boost. The point estimate of the intangibles index is statistically significant though small in magnitude; adding one intangible investment activity is associated with a 0.6 percentage point increase in the likelihood of having a greater than five percent increase in productivity $(0.051 \times 1 / 8=0.064) .15$ Given that the unconditional probability of an increase of this magnitude is about $32 \%$, this is a relatively unexciting lottery ticket, which makes it easy to understand why the mean effect is small and statistically insignificant.

Given these hints of what looks like a possible effect of the intangible stock on productivity, we also estimated a crude stock version of the model, in which the total number of affirmative responses to the investment questions over the time period was related to end-ofperiod productivity levels (not reported). The sample in this specification is a balanced panel of firms that appear in the innovation modules of 2005, 2007, 2009 and 2011. We found a systematic negative relationship between end-of-period productivity and the accumulated stock of intangibles. Finally, to probe further whether the negative association between investment and subsequent productivity levels could be due to some kind of reverse causality, we

\footnotetext{
15 We also ran regressions where the dependent variable is an indicator for a larger than one and a larger than 15 percentage point increase in MFP. Results are similar, with positive but economically small estimates. Average marginal effects from the logit estimator are also similar.
} 
attempted to estimate a firm fixed-effects model (not reported). The results were noisy, with no statistically significant coefficient estimates, and the point estimate on the lagged intangibles index was negative $(-0.03)$

All of the results in Table 5 include age and competition variables. These are included mostly as controls, and the results for the intangible variables are not sensitive to whether or not these controls are included. For age, we find some weak evidence that younger firms (age 25) have lower productivity levels than the base group (age 6-10). ${ }^{16}$ When observing productivity changes, we find, not surprisingly, that the oldest firms are less likely to increase their productivity. For competition, we find some evidence of higher measured productivity for firms with captive markets and only 1 or 2 competitors, which is consistent with market power's allowing an increase in markups; this appears as higher productivity because our output measure is revenue.

Together, the results of Table 5 provide no robust evidence of a meaningful positive link between our measures of intangible investment and productivity. When modelling the level of MFP in columns (1) to (4), the point estimates are negative, and in modelling the change in MFP in columns (5) to (6), the point estimates are positive but small and statistically significant only for the 'lottery ticket' version. We discuss in Section 5 different possible interpretations of these results.

While our industry-year interacted effects allow the intercepts of the regression to vary flexibly, these estimates all constrain each industry to have the same coefficient on the intangibles measure. To investigate whether this is distorting the underlying relationships, Figure 4 presents separate coefficient estimates and 95 percent confidence intervals of the intangibles index for each level 1 industry, using the regression model of column (1) of Table 5.

\footnotetext{
16 Note that the very youngest firms $(<2$ years $)$ cannot be included in this regression because we are looking at productivity as a function of intangible investment 2 years previous.
} 
While most of the estimates are statistically insignificant (presumably due to smaller sample sizes), there is a general tendency towards negative rather than positive coefficients. Further, there is no meaningful pattern to the positives and negatives, with the negative and statistically significant coefficients appearing in two high-intangible industries (finance and arts) and one low-intangible industry (agriculture). Consequently, while this does not give us a particularly clear picture, it again calls into question any hypothesis of a positive effect of intangibles on productivity.

Figure 4: Intangibles-index effect on MFP, by industry

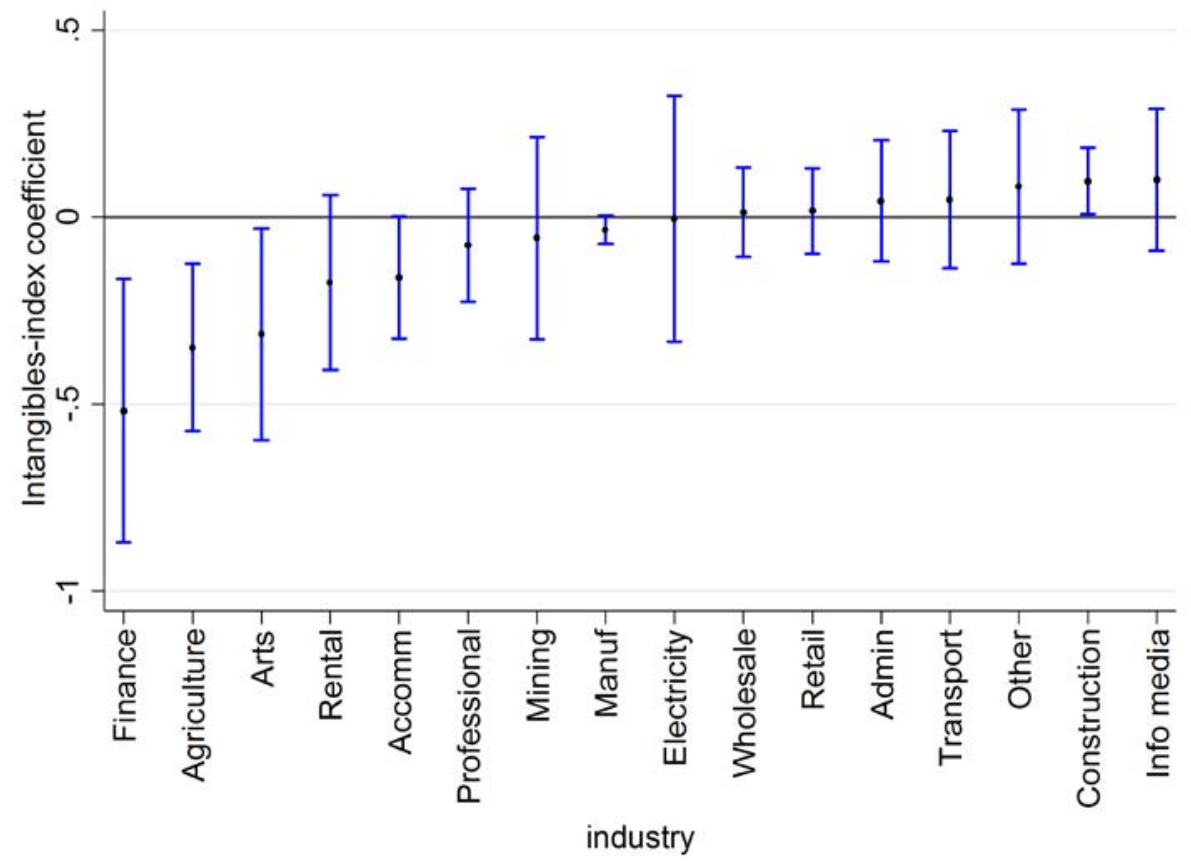

Notes: This figure presents the results of specifications that replicate column (1) of Table 5, run separately by industry. Coefficient estimates and $95 \%$ confidence intervals are shown. Industries are described in Appendix Table 3.

\subsubsection{Profitability and labour productivity}

Table 6 similarly examines the relationship between firm performance and past intangibles, but measures firm performance using profitability and labour productivity among large (above median size) firms.

Table 7 repeats this for small (below median size) firms, because in each regression Chow tests strongly reject the null hypothesis of no parameter differences between small and large firms. In standard economic theory, firms do not care about their productivity, per se, but we 
assume they are trying to maximize profits. If so, then a (presumably costly) investment activity will only be undertaken if it yields a reasonable return on that investment. Since the firms' investments in intangible assets are not included in the measured capital stock of the firm, the presence of such a return on intangible assets should be reflected in higher profitability measured relative to the observed capital stock.

Nevertheless, we find little evidence of a positive relationship for profitability for large and small firms: In both Table 6 and 7 the coefficient estimate of the intangibles index is negative, large in magnitude, and statistically significant when modelling the level of profitability in column (1); is small in magnitude and statistically insignificant when modelling the change in profitability in column (3); and is positive, small in magnitude and statistically insignificant in column (5) when modelling whether a firm experienced a larger than five percent increase in profitability. ${ }^{17}$

Labour productivity (value added per worker) is generally expected to rise as the result of any investment, because providing each worker with more capital should increase output per worker. For large firms, column (2) of Table 6 shows a positive relationship between intangible investment and the level of labour productivity, while column (4) shows a positive relationship between intangible investment and the change in labour productivity. For example, the point estimate of column (4) suggests an increase in the intangibles index that corresponds to one out of eight more activites is associated with about a 0.8 percentage increase in labour productivity (0.061 x 1/8=0.0076). Column (6) shows a positive and statistically significant relationship between intangible investment and the likelihood of a firm's having increased labour productivity by at least five percent over the previous two years.

\footnotetext{
17 OLS estimates in columns (5) and (6) are similar to the average marginal effects from logit estimates. We exclude firms with negative or zero profitability in these regressions, both in Table 6 and Table 7, because we use the log transformation in columns (1) and (3). We similarly exclude firms with negative or zero profit in Appendix Table 7, and firms with negative or zero labour productivity in Table 6 and 7 when modelling labour productivity.
} 
Table 7 shows that these relationships tend to be smaller for small firms (and statistically insignificant in columns (2) and (4)), though still positive.

How do we reconcile the positive link between the intangibles index and labour productivity, when we found no such relationship for MFP or profitability? This could occur if intangible investment is associated with an increase in the amount of conventional capital per worker, whether causally or coincidentally. We will see in Section 4.4 that intangible investment is associated with large increases in revenue, capital and labour, but not with capital intensity, which leaves the puzzle somewhat unresolved.

Finally, to explore a possible "growth without profitability" story and motivate the links with firm growth that will be explored in Section 4.4, Appendix Table 7 estimates versions of Eq. (2) where the dependent variable is the level, change, or an indicator for meaningful change of absolute profit rather than profitability (profit per unit of capital). Absolute profit is not the best measure of performance, as it will tend to be higher for larger firms just because they are larger and have more capital. Nonetheless, firms looking to create a presence may be content with increasing absolute profits.

Column (1) shows a large and statistically significant relationship between the intangibles index and the level of profits, implying taking up one out of eight more intangible activities is associated with a 19 percent increase in profits. This may reflect selection by firms, as we know that larger firms tend to report more investment and will tend to have higher absolute profits. Columns (2) to (4) instead examine changes in profits within a firm, and imply positive associations (though statistically insignificant in column (2)) with the intangibles index. We explore this "growth without profitability" story in more detail in Section 4.4. 
Table 6: Firm performance and past intangible investment among large firms: profitability and labour productivity

\begin{tabular}{|c|c|c|c|c|c|c|}
\hline Dependent variable: & $\begin{array}{c}\text { Profitability } \\
\text { (ln) } \\
(1)\end{array}$ & $\begin{array}{c}\text { Labour } \\
\text { productivity } \\
(\ln ) \\
(2) \\
\end{array}$ & $\begin{array}{c}\text { 2-yr change in } \\
\text { log profitability } \\
(3)\end{array}$ & $\begin{array}{c}\text { 2-yr change in log } \\
\text { labour } \\
\text { productivity } \\
(4)\end{array}$ & $\begin{array}{c}\text { Indicator for } \\
>5 \% \text { increase in } \\
\text { profitability } \\
(5)\end{array}$ & $\begin{array}{c}\text { Indicator for }>5 \% \\
\text { increase in labour } \\
\text { productivity } \\
(6)\end{array}$ \\
\hline Intangibles index (2-yr lagged) & $\begin{array}{c}-0.295^{* * *} \\
(0.087)\end{array}$ & $\begin{array}{c}0.179 * * * \\
(0.046)\end{array}$ & $\begin{array}{c}0.009 \\
(0.076)\end{array}$ & $\begin{array}{c}0.061^{*} \\
(0.034)\end{array}$ & $\begin{array}{c}0.012 \\
(0.043)\end{array}$ & $\begin{array}{c}0.101^{* * *} \\
(0.038)\end{array}$ \\
\hline Doesn't-know intangibles index (2-yr lagged) & $\begin{array}{c}0.085 \\
(0.165)\end{array}$ & $\begin{array}{c}0.146 \\
(0.128)\end{array}$ & $\begin{array}{c}0.144 \\
(0.182)\end{array}$ & $\begin{array}{c}0.002 \\
(0.076)\end{array}$ & $\begin{array}{c}0.128 \\
(0.098)\end{array}$ & $\begin{array}{c}0.057 \\
(0.093)\end{array}$ \\
\hline Age 2-5 & $\begin{array}{c}-0.018 \\
(0.078)\end{array}$ & $\begin{array}{c}-0.091^{* *} \\
(0.046)\end{array}$ & $\begin{array}{c}0.042 \\
(0.082)\end{array}$ & $\begin{array}{c}-0.057 \\
(0.041)\end{array}$ & $\begin{array}{c}0.017 \\
(0.046)\end{array}$ & $\begin{array}{l}-0.009 \\
(0.041)\end{array}$ \\
\hline Age 11-20 & $\begin{array}{l}-0.066 \\
(0.061)\end{array}$ & $\begin{array}{c}0.057^{*} \\
(0.031)\end{array}$ & $\begin{array}{c}-0.021 \\
(0.056)\end{array}$ & $\begin{array}{c}-0.005 \\
(0.023)\end{array}$ & $\begin{array}{l}-0.026 \\
(0.030)\end{array}$ & $\begin{array}{c}0.005 \\
(0.027)\end{array}$ \\
\hline Age $21+$ & $\begin{array}{l}-0.050 \\
(0.059)\end{array}$ & $\begin{array}{c}0.046 \\
(0.031)\end{array}$ & $\begin{array}{c}-0.041 \\
(0.052)\end{array}$ & $\begin{array}{c}-0.019 \\
(0.023)\end{array}$ & $\begin{array}{l}-0.045 \\
(0.029)\end{array}$ & $\begin{array}{l}-0.005 \\
(0.026)\end{array}$ \\
\hline Perceived captive market & $\begin{array}{l}-0.055 \\
(0.150)\end{array}$ & $\begin{array}{c}0.175 \\
(0.122)\end{array}$ & $\begin{array}{c}0.032 \\
(0.101)\end{array}$ & $\begin{array}{l}-0.046 \\
(0.050)\end{array}$ & $\begin{array}{l}-0.061 \\
(0.072)\end{array}$ & $\begin{array}{l}-0.039 \\
(0.059)\end{array}$ \\
\hline Perceived 1 or 2 competitors & $\begin{array}{c}0.024 \\
(0.059)\end{array}$ & $\begin{array}{c}-0.009 \\
(0.028)\end{array}$ & $\begin{array}{c}0.043 \\
(0.050)\end{array}$ & $\begin{array}{c}0.025 \\
(0.021)\end{array}$ & $\begin{array}{c}-0.001 \\
(0.026)\end{array}$ & $\begin{array}{c}0.009 \\
(0.024)\end{array}$ \\
\hline Perceived many competitors, none dominant & $\begin{array}{l}-0.040 \\
(0.053)\end{array}$ & $\begin{array}{c}-0.068^{* *} \\
(0.027)\end{array}$ & $\begin{array}{c}-0.093^{* *} \\
(0.047)\end{array}$ & $\begin{array}{c}-0.030 \\
(0.020)\end{array}$ & $\begin{array}{c}-0.082^{* * *} \\
(0.025)\end{array}$ & $\begin{array}{c}-0.071^{* * *} \\
(0.023)\end{array}$ \\
\hline Doesn't know competition & $\begin{array}{c}0.133 \\
(0.132)\end{array}$ & $\begin{array}{c}-0.097 \\
(0.085)\end{array}$ & $\begin{array}{c}0.066 \\
(0.156)\end{array}$ & $\begin{array}{c}-0.030 \\
(0.048)\end{array}$ & $\begin{array}{l}-0.050 \\
(0.080)\end{array}$ & $\begin{array}{c}-0.073 \\
(0.064)\end{array}$ \\
\hline Year* level 3 industry FE & Yes & Yes & Yes & Yes & Yes & Yes \\
\hline Observations & 3,381 & 3,897 & 2,838 & 3,456 & 2,838 & 3,456 \\
\hline Small firm cut-off (FTE) & 33.4 & 33.4 & 35.7 & 35.1 & 35.7 & 34.9 \\
\hline Proportion of successes & & & & & 0.377 & 0.390 \\
\hline R squared & 0.305 & 0.488 & 0.251 & 0.189 & 0.223 & 0.196 \\
\hline
\end{tabular}

Notes: This table presents the coefficients from OLS regressions at the firm-year level. The sample is limited to odd March-years from 2005 to 2013 and firms that are above the small firm cut-off which is the median firm size and unique for each regression column. The omitted category for age is $6-10$ years, and the omitted category for competition is 'many competitors, some dominant'. Standard errors, in parentheses, are robust and clustered at the firm level. The reported numbers of observations have been randomly rounded to the nearest multiple of 3, as required by Statistics NZ confidentiality rules. Asterisks denote: *** $\mathrm{p}<0.01,{ }^{* *} \mathrm{p}<0.05, * \mathrm{p}<0.10$. 
Table 7: Firm performance and past intangible investment among small firms: profitability and labour productivity

\begin{tabular}{|c|c|c|c|c|c|c|}
\hline Dependent variable: & $\begin{array}{l}\text { Profitability } \\
\text { (ln) } \\
(1) \\
\end{array}$ & $\begin{array}{c}\text { Labour } \\
\text { productivity } \\
\text { (ln) } \\
(2) \\
\end{array}$ & $\begin{array}{c}\text { 2-yr change in } \\
\text { log profitability } \\
(3)\end{array}$ & $\begin{array}{c}\text { 2-yr change in log } \\
\text { labour } \\
\text { productivity } \\
(4)\end{array}$ & $\begin{array}{c}\text { Indicator for } \\
>5 \% \text { increase in } \\
\text { profitability } \\
(5)\end{array}$ & $\begin{array}{c}\text { Indicator for }>5 \% \\
\text { increase in labour } \\
\text { productivity } \\
(6)\end{array}$ \\
\hline Intangibles index (2-yr lagged) & $\begin{array}{c}-0.324^{* * *} \\
(0.093)\end{array}$ & $\begin{array}{c}0.060 \\
(0.057)\end{array}$ & $\begin{array}{c}-0.033 \\
(0.086)\end{array}$ & $\begin{array}{c}0.029 \\
(0.042)\end{array}$ & $\begin{array}{c}0.061 \\
(0.046)\end{array}$ & $\begin{array}{l}0.091^{* *} \\
(0.040)\end{array}$ \\
\hline Doesn't-know intangibles index (2-yr lagged) & $\begin{array}{l}-0.278^{*} \\
(0.165)\end{array}$ & $\begin{array}{c}-0.079 \\
(0.086)\end{array}$ & $\begin{array}{c}-0.333^{* *} \\
(0.164)\end{array}$ & $\begin{array}{c}-0.057 \\
(0.071)\end{array}$ & $\begin{array}{l}-0.131^{*} \\
(0.076)\end{array}$ & $\begin{array}{c}0.007 \\
(0.074)\end{array}$ \\
\hline Age $2-5$ & $\begin{array}{c}-0.111 \\
(0.068)\end{array}$ & $\begin{array}{c}-0.050 \\
(0.038)\end{array}$ & $\begin{array}{c}-0.015 \\
(0.064)\end{array}$ & $\begin{array}{c}0.039 \\
(0.034)\end{array}$ & $\begin{array}{c}-0.026 \\
(0.034)\end{array}$ & $\begin{array}{c}-0.004 \\
(0.031)\end{array}$ \\
\hline Age $11-20$ & $\begin{array}{c}-0.025 \\
(0.050)\end{array}$ & $\begin{array}{c}0.002 \\
(0.031)\end{array}$ & $\begin{array}{c}0.014 \\
(0.047)\end{array}$ & $\begin{array}{c}-0.022 \\
(0.025)\end{array}$ & $\begin{array}{l}-0.009 \\
(0.025)\end{array}$ & $\begin{array}{c}-0.045^{* *} \\
(0.022)\end{array}$ \\
\hline Age $21+$ & $\begin{array}{l}-0.101^{*} \\
(0.057)\end{array}$ & $\begin{array}{c}0.007 \\
(0.033)\end{array}$ & $\begin{array}{c}-0.064 \\
(0.046)\end{array}$ & $\begin{array}{c}-0.051^{* *} \\
(0.024)\end{array}$ & $\begin{array}{c}-0.041 \\
(0.025)\end{array}$ & $\begin{array}{c}-0.060^{* * *} \\
(0.023)\end{array}$ \\
\hline Perceived captive market & $\begin{array}{c}-0.124 \\
(0.112)\end{array}$ & $\begin{array}{c}-0.058 \\
(0.088)\end{array}$ & $\begin{array}{c}-0.041 \\
(0.075)\end{array}$ & $\begin{array}{c}0.010 \\
(0.039)\end{array}$ & $\begin{array}{c}-0.042 \\
(0.050)\end{array}$ & $\begin{array}{c}0.037 \\
(0.046)\end{array}$ \\
\hline Perceived 1 or 2 competitors & $\begin{array}{c}0.030 \\
(0.052)\end{array}$ & $\begin{array}{c}0.031 \\
(0.031)\end{array}$ & $\begin{array}{c}0.056 \\
(0.053)\end{array}$ & $\begin{array}{c}0.000 \\
(0.021)\end{array}$ & $\begin{array}{c}0.034 \\
(0.025)\end{array}$ & $\begin{array}{l}0.053^{* *} \\
(0.023)\end{array}$ \\
\hline Perceived many competitors, none dominant & $\begin{array}{c}-0.056 \\
(0.050)\end{array}$ & $\begin{array}{c}-0.004 \\
(0.028)\end{array}$ & $\begin{array}{c}0.084^{*} \\
(0.048)\end{array}$ & $\begin{array}{c}0.021 \\
(0.024)\end{array}$ & $\begin{array}{c}0.004 \\
(0.025)\end{array}$ & $\begin{array}{c}0.028 \\
(0.024)\end{array}$ \\
\hline Doesn't know competition & $\begin{array}{c}0.081 \\
(0.097)\end{array}$ & $\begin{array}{c}-0.137^{* *} \\
(0.060)\end{array}$ & $\begin{array}{c}0.116 \\
(0.084)\end{array}$ & $\begin{array}{l}-0.089 * \\
(0.048)\end{array}$ & $\begin{array}{c}-0.001 \\
(0.049)\end{array}$ & $\begin{array}{l}-0.016 \\
(0.042)\end{array}$ \\
\hline Year* level 3 industry FE & Yes & Yes & Yes & Yes & Yes & Yes \\
\hline Observations & 3,381 & 3,897 & 2,838 & 3,456 & 2,838 & 3,456 \\
\hline Small firm cut-off (FTE) & 33.4 & 33.4 & 35.7 & 35.1 & 35.7 & 34.9 \\
\hline Proportion of successes & & & & & 0.361 & 0.388 \\
\hline R squared & 0.322 & 0.333 & 0.193 & 0.226 & 0.217 & 0.178 \\
\hline
\end{tabular}




\subsection{Intangibles and the distribution of firm performance}

The previous section suggested that there is no positive association on average between intangible investment and productivity. If, however, different firms use intangible investment in different ways, it is possible that this lack of an effect on average is hiding a significant positive effect for some firms. One might think, for example, that for poorly performing firms, intangible investment is a mechanism to pull themselves up, while for successful firms it is pointless gilding of the lily. Conversely, one might think that poorly performing firms do everything badly, including making ineffective intangible investments, whereas well-run firms are able to make intangible investments that add real value. Either of these statements suggest that whether and to what extent intangible investment is productive varies depending on the underlying productivity of the firm.

Quantile regression methods allow one to explore whether the effect of a variable differs for different levels of the dependent variable. The model estimates different effects for each quantile of firm performance conditional on past intangibles and other covariates. Our model then looks like equation (2) with the same dependent and explanatory variables; but the estimator models the conditional quantile function rather than the conditional expectation function. Industry-specific time trends remain in the model for flexibility.

We also use the methodology of Firpo et al. (2009) to run unconditional quantile regressions that relate different parts of the unconditional distribution of firm performance to past intangible expenditure. The difference between the two methods lies in exactly which firms are in each quantile. If we consider the lowest quantile, for example, the conditional method puts in that quantile the firms whose performance is worst relative to what would be expected based on their other characteristics. It would include in the lowest quantile firms whose performance is not actually so bad, if their characteristics are such that we would expect their performance to be very good. In contrast, the unconditional method includes in the lowest quantile those firms whose performance is worst in absolute terms, regardless of what we might expect based on their characteristics. 
In our case, we do not have a particular theory about how the effect of intangibles might vary with performance; we are simply exploring whether there is important variation underlying the average. For this reason, we try both approaches, though in fact they show similar qualitative pictures.

Table 8 presents results from conditional quantile regressions in odd columns, and unconditional quantile regressions in even columns. ${ }^{18}$ Columns (1) and (2) show the results for the intangibles index, and columns (3) and (4) use the dummy variable for reporting positive intangible expenditure. The results show that the average negative association of past intangible investment on current productivity is not limited to particular portions of the productivity distribution. There is a general pattern of negative effects, although not all are statistically significant. There is no quantile that shows a significantly positive effect for any version of the model.

The last four columns repeat this exercise but with log labour productivity as an alternative measure of firm performance. Columns (5) and (6) suggest a positive relationship between past intangibles and the various quantiles of labour productivity, with the relationship increasing as we move up the labour productivity distribution. For example, column (5) shows that increasing the past intangibles by one activity is associated with a 1.4 percent increase in the conditional $10^{\text {th }}$ percentile of labour productivity $(.112 \times 1 / 8)$; this increases to about a 1.8 percent increase in the conditional $90^{\text {th }}$ percentile (.142 x 1/8). Similarly, in columns (7) and (8) the coefficient estimates are consistently positive and increasing with the quantile when using an indicator for reporting any intangible expenditure.

Taken together, these results do not support the hypothesis that intangible investment behaves quite differently for firms at different points in the productivity distribution. For MFP, the association with recent past intangible investment is negative across all quantiles. For

18 In conditional quantile regressions we cluster standard errors at the firm level using the package that was created by Machado et al. (2015). 
labour productivity, it is positive across all quantiles, with some evidence of a slightly larger effect for the most productive firms.

\subsection{Changes in inputs and outputs}

One potential explanation for the puzzling negative relationship between intangible investment and MFP in the previous sections is that firms are focused on growing; perhaps rather than increasing performance in the short-term, intangible investment is intended to marshall resources that will lead to growth, either as an end in itself or as a precondition for eventual performance gains. In this section, we investigate one of the conditions that are necessary for this to be true: Do firms increase their inputs and outputs after investing in intangibles?

These regressions take the form:

$$
y_{j k t}=\beta_{0}+\beta_{1} \text { intangibles }_{j k t-1}+\beta_{2} \text { history }_{j k t-1}+\rho_{k t}+\varepsilon_{j k t},
$$

where $y_{j k t}$ denotes either the firm's log of gross output, log of labour, log of capital, or log of capital intensity (capital per unit of labour); 'history' denotes the vector of past output, labour, and capital, all in log form; and $\rho_{k t}$ denotes industry-specific year effects. In alternative specifications, we drop the 'history' variable and include firm fixed effects, and thereby focus on within-firm variation in intangibles and how this translates to subsequent activity.

Table 9 presents the results from such regressions, with the 'history' specifications in odd columns and the firm fixed effect specifications in even columns. The dependent variables are all in log form, so that coefficient estimates are interpreted as elasticities for the logged input and output covariates, and as semi-elasticities for the intangibles index. Column (1) shows that output tends to increase after intangible investment; an increase in the intangibles index corresponding to one additional intangible investment activity out of eight is associated with a 1.4 percent increase in output $(0.112 \times 1 / 8)$ for a given history of past inputs and outputs. Column (2) shows an economically and statistically significant relationship remains when including firm fixed effects; an increase in the intangibles index corresponding to one additional activity out of eight is associated with a one percent increase in output $(0.079 \times 1 / 8)$. 
Table 8: Distribution of firm performance and past intangible investment

\begin{tabular}{|c|c|c|c|c|c|c|c|c|}
\hline \multirow{3}{*}{ Quantile being estimated } & \multicolumn{4}{|c|}{ Dependent variable: MFP } & \multicolumn{4}{|c|}{ Dependent variable: log labour productivity } \\
\hline & $\begin{array}{l}\text { Coeff on past } \\
\text { intangibles } \\
\text { index }\end{array}$ & $\begin{array}{c}\text { Coeff on past } \\
\text { intangibles } \\
\text { index }\end{array}$ & $\begin{array}{c}\text { Coeff on any } \\
\text { intangible } \\
\text { expenditure } \\
\text { dummy }\end{array}$ & $\begin{array}{l}\text { Coeff on any } \\
\text { intangible } \\
\text { expenditure } \\
\text { dummy }\end{array}$ & $\begin{array}{l}\text { Coeff on past } \\
\text { intangibles } \\
\text { index }\end{array}$ & $\begin{array}{c}\text { Coeff on past } \\
\text { intangibles } \\
\text { index }\end{array}$ & $\begin{array}{l}\text { Coeff on any } \\
\text { intangible } \\
\text { expenditure } \\
\text { dummy }\end{array}$ & $\begin{array}{c}\text { Coeff on any } \\
\text { intangible } \\
\text { expenditure } \\
\text { dummy }\end{array}$ \\
\hline & $(1)$ & $(2)$ & (3) & $(4)$ & (5) & $(6)$ & (7) & $(8)$ \\
\hline 10th percentile & $\begin{array}{l}-0.012 \\
(0.024)\end{array}$ & $\begin{array}{c}-0.069^{* * *} \\
(0.027)\end{array}$ & $\begin{array}{c}-0.003 \\
(0.013)\end{array}$ & $\begin{array}{c}0.011 \\
(0.017)\end{array}$ & $\begin{array}{l}0.112^{* *} \\
(0.051)\end{array}$ & $\begin{array}{c}0.128^{* * *} \\
(0.045)\end{array}$ & $\begin{array}{l}0.059^{* *} \\
(0.028)\end{array}$ & $\begin{array}{c}0.068^{* * *} \\
(0.025)\end{array}$ \\
\hline 25th percentile & $\begin{array}{c}-0.037^{* *} \\
(0.016)\end{array}$ & $\begin{array}{c}-0.040^{* * *} \\
(0.015)\end{array}$ & $\begin{array}{l}-0.014^{*} \\
(0.008)\end{array}$ & $\begin{array}{l}-0.015^{*} \\
(0.008)\end{array}$ & $\begin{array}{c}0.139 * * * \\
(0.033)\end{array}$ & $\begin{array}{c}0.150^{* * *} \\
(0.033)\end{array}$ & $\begin{array}{l}0.051^{* * *} \\
(0.019)\end{array}$ & $\begin{array}{c}0.063^{* * *} \\
(0.019)\end{array}$ \\
\hline Median & $\begin{array}{l}-0.035^{* *} \\
(0.015)\end{array}$ & $\begin{array}{c}-0.040^{* * *} \\
(0.012)\end{array}$ & $\begin{array}{c}-0.011 \\
(0.008)\end{array}$ & $\begin{array}{c}-0.014^{* *} \\
(0.007)\end{array}$ & $\begin{array}{c}0.124^{* * *} \\
(0.029)\end{array}$ & $\begin{array}{l}0.149^{* * *} \\
(0.030)\end{array}$ & $\begin{array}{c}0.057^{* * *} \\
(0.016)\end{array}$ & $\begin{array}{c}0.072^{* * *} \\
(0.016)\end{array}$ \\
\hline 75th percentile & $\begin{array}{l}-0.037^{*} \\
(0.019)\end{array}$ & $\begin{array}{c}-0.042^{* * *} \\
(0.016)\end{array}$ & $\begin{array}{l}-0.016 \\
(0.010)\end{array}$ & $\begin{array}{l}-0.021^{* *} \\
(0.009)\end{array}$ & $\begin{array}{c}0.125^{* * *} \\
(0.039)\end{array}$ & $\begin{array}{c}0.154^{* * *} \\
(0.037)\end{array}$ & $\begin{array}{c}0.062^{* * *} \\
(0.018)\end{array}$ & $\begin{array}{c}0.088^{* * *} \\
(0.022)\end{array}$ \\
\hline 90th percentile & $\begin{array}{c}-0.074^{* * *} \\
(0.025)\end{array}$ & $\begin{array}{c}-0.085^{* * *} \\
(0.032)\end{array}$ & $\begin{array}{l}-0.012 \\
(0.015)\end{array}$ & $\begin{array}{l}-0.023 \\
(0.018)\end{array}$ & $\begin{array}{l}0.148^{* * *} \\
(0.053)\end{array}$ & $\begin{array}{c}0.227^{* * *} \\
(0.058)\end{array}$ & $\begin{array}{l}0.081^{* * *} \\
(0.027)\end{array}$ & $\begin{array}{l}0.104^{* * *} \\
(0.033)\end{array}$ \\
\hline $\begin{array}{l}\text { Year * level } 3 \text { industry FE } \\
\text { Unconditional quantile re }\end{array}$ & $\begin{array}{l}\text { Yes } \\
\text { sion }\end{array}$ & $\begin{array}{l}\text { Yes } \\
\text { Yes }\end{array}$ & Yes & $\begin{array}{l}\text { Yes } \\
\text { Yes }\end{array}$ & Yes & $\begin{array}{l}\text { Yes } \\
\text { Yes }\end{array}$ & Yes & $\begin{array}{l}\text { Yes } \\
\text { Yes }\end{array}$ \\
\hline Observations & 7,884 & 7,884 & 6,075 & 6,075 & 7,794 & 7,794 & 5,997 & 5,997 \\
\hline
\end{tabular}

Notes: This table presents the coefficients from quantile regressions at the firm-year level, where the dependent variable is as described in the column headers. Each row shows estimates of the association of past intangible investment on different part of the conditional distribution of performance (or unconditional, in every second column). Columns vary by whether the distribution is conditional or unconditional, and the past intangibles measure. The regressions that estimate the coefficient on the intangibles index also include as controls the 'doesn't-know' intangibles index, age-category dummy variables, and competition dummy variables. The sample is limited to March-years from 2005 to 2011. Standard errors, in parentheses, are robust and clustered at the firm level in conditional quantile regressions. The reported numbers of observations have been randomly rounded to the nearest multiple of 3 , as required by Statistics $\mathrm{NZ}$ confidentiality rules. Asterisks denote: ${ }^{* * *} \mathrm{p}<0.01,{ }^{* *} \mathrm{p}<0.05,{ }^{*} \mathrm{p}<0.10$. 
Columns (3) and (4) use the log of labour as the dependent variable. The results are similar; an increase of one-eigth in the intangibles index is associated with around a one percent increase for both specifications. Similarly, columns (5) and (6) use the log of capital as the dependent variable, with a coefficient on the intangibles index of .12 when controlling for a firm's history of inputs and outputs, and .08 with firm fixed effects.

As noted above, the positive association of intangible investment with labour productivity when it is not positively associated with MFP suggests that perhaps intangible investment is associated with an increase in conventional capital intensity. The results in columns (3) - (6) do not show an obvious tendency in terms of the relative increase in capital and labour. The last two columns of Table 9 focus directly on the log of capital intensity, measured as capital per unit of labour. The positive point estimate of 0.028 in column (7) is economically small and statistically insignificant, and the negative point estimate of -0.036 in column (8) with firm fixed effects is similarly economically small and statistically insignificant.

Together, the results of Table 9 provide strong evidence that increases in the intangibles index are associated with increases in firm inputs and outputs; firms expand after intangible investment. But capital intensity appears unchanged; there is no clear difference between the growth of capital and labour inputs. This leaves unresolved the puzzle of the positive associations with labour productivity that were shown in previous sections; intangiblesinvesting firms are using more labour and capital after investment, in roughly the same proportion, and it appears that they subsequently have higher labour productivity but not higher MFP. 
Table 9: Intangible investment and growth of inputs and output

\begin{tabular}{|c|c|c|c|c|c|c|c|c|}
\hline Dependent variable: & $\begin{array}{c}\text { Gross } \\
\text { output } \\
(\ln )\end{array}$ & $\begin{array}{l}\text { Gross } \\
\text { output } \\
\text { (ln) }\end{array}$ & Labour (ln) & Labour (ln) & Capital (ln) & Capital (ln) & $\begin{array}{l}\text { Capital } \\
\text { intensity } \\
\text { (ln) }\end{array}$ & $\begin{array}{c}\text { Capital } \\
\text { intensity } \\
(\ln )\end{array}$ \\
\hline Intangibles index (2-yr lagged) & $\begin{array}{c}0.112 * * * \\
(0.024)\end{array}$ & $\begin{array}{c}0.079 * * \\
(0.033)\end{array}$ & $\begin{array}{c}0.092 * * * \\
(0.021)\end{array}$ & $\begin{array}{c}0.113^{* * *} \\
(0.030)\end{array}$ & $\begin{array}{c}0.120 * * * \\
(0.024)\end{array}$ & $\begin{array}{c}0.077 * * \\
(0.036)\end{array}$ & $\begin{array}{c}0.028 \\
(0.023)\end{array}$ & $\begin{array}{c}-0.036 \\
(0.034)\end{array}$ \\
\hline Doesn't-know intangibles index (2-yr lagged) & $\begin{array}{l}-0.038 \\
(0.059)\end{array}$ & $\begin{array}{c}0.044 \\
(0.048)\end{array}$ & $\begin{array}{l}-0.003 \\
(0.042)\end{array}$ & $\begin{array}{c}0.054 \\
(0.043)\end{array}$ & $\begin{array}{c}-0.012 \\
(0.070)\end{array}$ & $\begin{array}{c}0.050 \\
(0.055)\end{array}$ & $\begin{array}{c}-0.008 \\
(0.057)\end{array}$ & $\begin{array}{l}-0.005 \\
(0.052)\end{array}$ \\
\hline Labour (In) (2-yr lagged) & $\begin{array}{c}0.080 * * * \\
(0.016)\end{array}$ & & $\begin{array}{c}0.929 * * * \\
(0.013)\end{array}$ & & $\begin{array}{c}0.031 * * \\
(0.016)\end{array}$ & & $\begin{array}{c}0.860 * * * \\
(0.012)\end{array}$ & \\
\hline Capital (In) (2-yr lagged) & $\begin{array}{c}0.034^{* * *} \\
(0.009)\end{array}$ & & $\begin{array}{l}-0.002 \\
(0.007)\end{array}$ & & $\begin{array}{c}0.858 * * * \\
(0.013)\end{array}$ & & $\begin{array}{c}-0.898 * * * \\
(0.016)\end{array}$ & \\
\hline Number of firms & & 6,273 & & 6,273 & & 6,273 & & 6,273 \\
\hline$R$ squared & 0.919 & 0.114 & 0.903 & 0.118 & 0.924 & 0.096 & 0.820 & 0.080 \\
\hline
\end{tabular}




\subsection{Reported satisfaction and intangible investment}

The results so far suggest that intangible investment is associated with growth, but with no positive effect on firms' productivity or profitability. This led us to explore further what might be happening when firms invest in intangibles that foster growth while not increasing profits or productivity. One possibility is that intangibles support improvement in 'soft' aspects of firm performance that are not reflected in the short run in productivity or profitability.

As an exploration of this possibility, we examine whether past intangible investment is associated with higher firm-reported customer and employee satisfaction for firms that look otherwise similar. Our baseline model is a linear probability model and takes the form:

$$
y_{j k t}=\beta_{0}+\beta_{1} \text { intangibles }_{j k t-1}+\beta_{2} \text { confidence }_{j k t-1}+\gamma_{k}+\delta_{t}+\varepsilon_{j k t},
$$

where $j$ denotes firm, $k$ denotes industry, and $t$ denotes year, and $y_{j k t}$ is an indicator for the firm reporting soft success (either high customer or high employee satisfaction). We derive this indicator of success from a question that asks whether a business is lower, on par with, or higher than competitors when it comes to customer and employee satisfaction (as described in Section 3.1); the dependent variable takes on the value one if the firm reports high customer/employee satisfaction, and zero otherwise, ignoring the 'don't know' answers. The 'confidence' variable is described in Section 3.1 and controls for the fact that some managers may generically overstate how great their firm is. We also include industry-specific year effects to allow each industry to have its own time trend of reported satisfaction. Hence we examine whether past intangible investment is associated with more customer and employee satisfaction for comparable firms reporting similar levels of quality; flexibility; time to produce goods and services; and costs.

Table 10 presents the results of this estimation. Column (1) shows a positive and statistically significant relationship between the lagged intangibles index and firm-reported customer satisfaction. The coefficient estimate of 0.092 indicates that adding one additional intangible activity is associated with 1.1 percentage point increase $(0.092 \times 1 / 8)$ in the probability of reporting high customer satisfaction. 
One concern with such a specification is that certain managers may be overly confident about their firm's quality, causing them to overstate the satisfaction of their customers and employees. Furthermore, these same respondent-specific traits may correspond with reporting intangible investment; overly confident managers may like to report that they are training their employees, developing new marketing strategies, and doing other admirable-sounding activities. If this omitted-variable hypothesis is correct, our coefficient estimate of the intangibles index will be upwardly biased in column (1). We attempt to control for the 'confidence' of the survey respondent with the use of the confidence index as a control, as described in Section 3.1 and constructed as the average reported category for questions on relative costs; relative time to provide goods and services; relative quality of goods and services; and relative flexibility.

Column (2) of Table 10 shows that including the confidence index as a control decreases but leaves positive the point estimate of the intangibles index. As expected, the coefficient estimate on the confidence index is positive, which indicates that firms that answered higher on the underlying questions tend to report higher customer satisfaction. Column (3) instead controls for respondent confidence by including dummy variables for each of the categories that make up the confidence index. The coefficient estimate of the intangibles index loses statistical significance though remains positive.

Columns (4) to (6) replicate columns (1) to (3) but with employee satisfaction as the dependent variable. A similar pattern emerges: Intangible investment is positively associated with employee satisfaction, with the relationship becoming weaker but remaining positive and statistically significant after attempting to control for the confidence of the firm. For example, column (5) indicates that adding one of the eight intangible activities is associated with a 0.75 percentage point increase $(0.06 \times 1 / 8)$ in the likelihood of reporting high employee satisfaction.

Appendix Table 8 replicates Table 10 but estimates logit models rather than linear probability models. ${ }^{19}$ The reported average marginal effects are very close to the corresponding point estimates from Table 10.

\footnotetext{
${ }^{19}$ We drop industry-specific year effects for empirical tractability, but leave in both year and industry fixed effects
} 
We have not established causality with these estimates; intangible investment may be correlated with the error term in these models due to omitted variable bias. There could be separate phenomena that increase both intangible investment and customer/employee satisfaction or reverse causality between satisfaction and intangible investment that cannot be solved by lagging our intangibles index. However, it is interesting that the finding holds after comparing similar firms within an industry, and controlling for how confident the firm is on other dimensions. This suggests a channel through which intangible investment may be affecting firms' outcomes.

\section{Conclusion}

A growing literature on intangible investment posits—and sometimes confirms empiricallythat such investment results in an intangible asset of the firm that improves firm performance. In the standard the model, the presence of this productive input that is not included among measured inputs should be reflected in higher productivity and profitability as conventionally measured.

Using firm-level data from the New Zealand, we link self-reported intangible investment activities -- including R\&D, employee training, marketing, and organisational restructuring -with measures of firm performance and activity. We find evidence of plausible variation in our intangible measures across different industries: Our measure of intangible investment is highest in 'information media and telecommunications'; 'manufacturing'; and 'professional, scientific and technical services'. It is lowest in 'agricultural, forestry and fishing'; and 'mining'.

Examining the characteristics of intangibles-investing firms, we find that intangible investment is decreasing with age; increasing with firm size; is unrelated to past output growth relative to the industry average; and is highest with a moderate amount of perceived competition. 
Table 10: Intangible Investment and Customer/Employee Satisfaction

\begin{tabular}{|c|c|c|c|c|c|c|}
\hline Dependent variable: & $\begin{array}{c}\text { High } \\
\text { customer } \\
\text { satisfaction } \\
\text { (1) }\end{array}$ & $\begin{array}{c}\text { High } \\
\text { customer } \\
\text { satisfaction } \\
\text { (2) }\end{array}$ & $\begin{array}{c}\text { High } \\
\text { customer } \\
\text { satisfaction } \\
\text { (3) }\end{array}$ & $\begin{array}{c}\text { High } \\
\text { employee } \\
\text { satisfaction } \\
\text { (4) }\end{array}$ & $\begin{array}{c}\text { High } \\
\text { employee } \\
\text { satisfaction } \\
\text { (5) }\end{array}$ & $\begin{array}{c}\text { High } \\
\text { employee } \\
\text { satisfaction } \\
(6)\end{array}$ \\
\hline Intangibles index (2-yr lagged) & $\begin{array}{l}0.092^{* * *} \\
(0.021)\end{array}$ & $\begin{array}{l}0.055^{* * *} \\
(0.019)\end{array}$ & $\begin{array}{c}0.008 \\
(0.016)\end{array}$ & $\begin{array}{l}0.085^{* * *} \\
(0.022)\end{array}$ & $\begin{array}{l}0.060^{* * *} \\
(0.021)\end{array}$ & $\begin{array}{l}0.034^{*} \\
(0.020)\end{array}$ \\
\hline Doesn't-know intangibles index (2-yr lagged) & $\begin{array}{c}-0.133^{* * *} \\
(0.047)\end{array}$ & $\begin{array}{c}-0.128^{* * *} \\
(0.041)\end{array}$ & $\begin{array}{c}-0.098^{* * *} \\
(0.219)\end{array}$ & $\begin{array}{c}-0.110^{* *} \\
(0.047)\end{array}$ & $\begin{array}{c}-0.105^{* *} \\
(0.044)\end{array}$ & $\begin{array}{l}-0.083^{*} \\
(0.043)\end{array}$ \\
\hline Confidence index (1-3) & & $\begin{array}{c}0.593^{* * *} \\
(0.012)\end{array}$ & & & $\begin{array}{c}0.418^{* * *} \\
(0.014)\end{array}$ & \\
\hline $\begin{array}{l}\text { Dummy variables for reported costs, time to } \\
\text { provide g\&s, quality and flexibility }\end{array}$ & & & Yes & & & Yes \\
\hline Year * level 3 industry FE & Yes & Yes & Yes & Yes & Yes & Yes \\
\hline Proportion of successes & 0.628 & 0.628 & 0.627 & 0.493 & 0.493 & 0.493 \\
\hline Observations & 13,293 & 13,269 & 13,173 & 12,636 & 12,603 & 12,522 \\
\hline
\end{tabular}


Intangible investment in the recent past appears negatively associated with MFP, though we do find a small, statistically significant positive effect of recent past intangible investment on the probability of enjoying a large productivity increase. When we examine intangibles and the distribution of MFP, we find a generally negative relationship across different quantiles, though it is most negative for the highest quantiles.

More generally, we have tried many different empirical formulations of the relationship and have found no framework in which strong positive effects of such investment on productivity or profitability can be detected. ${ }^{20}$ Typically, we would expect the associations shown to be upwardly biased due to unobserved attributes of good management being positively correlated with both intangible investment and productivity. This makes the negative relationship all the more puzzling. While there is a theoretical possibility of negative bias due to causality running from low productivity to intangible investment, this seems unlikely given that intangible investment seems unrelated to a firm's past output growth relative to the industry average.

Although we have not estimated a causal model, the data show an association between firm growth and intangible investment, and seem to be consistent with a story in which such investment allows the firm to attract additional inputs and increase its revenue. We have not pinned down the mechanisms by which this might work, but we do find that past investment is positively correlated with firm-reported customer and employee satisfaction. This finding holds after attempting to control for the possible tendency of some firms to overstate their accomplishments.

Given the weakness of the results, and their apparent inconsistency with theory, it is hard to draw strong conclusions from this analysis. The results may be driven by some combination of:

1. The BOS survey responses do not meaningfully reflect 'true' intangible investment.

\footnotetext{
${ }^{20}$ In addition to the models that we report herein, we also explored whether any individual forms of intangible investment or categories of such investment as used by Corrado et al. (2012) have positive associations with productivity. We found none.
} 
2. Our LBD-derived productivity and profitability measures do not accurately capture true productivity and profitability.

3. Intangible investment can increase productivity, but on average New Zealand firms are investing in the wrong assets, or are investing inefficiently.

4. Intangible investment does improve firm performance, but this effect is clouded by some kind of reverse causality or negative selection into intangible investment.

5. Intangible investment does improve firm performance, but with long and/or variable lags that make it impossible to identify empirically.

6. Firms invest in intangibles in pursuit of firm growth, even if such growth occurs at the expense of productivity and/or profitability.

7. Firms may invest in intangibles for benefits that are themselves intangible, such as customer and employee satisfaction.

8. Firms may investment in intangibles expecting that it will allow them to grow and become more profitable/productive, but the latter outcomes are mostly unrealized.

Explanation 1 has some plausibility: Self-reported answers to broad questions will never perfectly capture the phenomenon of interest. But given the systematic relationships in our regression analysis and the variation across industries, it seems that we are measuring realworld intangible investment to some extent, and it is difficult to imagine a systematic pattern of mismeasurement that would produce apparent negative effects. Similarly, mismeasurement of profitability and productivity (\#2) would seem more likely to yield no effect than a negative effect.

Explanation 3 is more a caveat on interpreting our results. Any analysis of this kind can say only what is, not what could be. But we explore whether any of the avenues of intangible investment in the data could be seen to have positive effects, and found none. And the measures that we do have are associated with measurable differences for firms-they grow faster. We cannot rule out that they could have had other effects if undertaken differently, but we are more inclined to focus on what did happen.

Explanation 4 seems implausible to us: Strong negative selection on MFP into intangibles would suggest something closer to a survival story in which firms invest in a last-ditch effort remain afloat. But our results show that investing firms tend to have had growth similar to the industry average, which is not consistent with a widespread survival motive.

Explanation 5 has surface plausibility: Intangible investment is associated with increased costs in the short run and so could manifest as a negative effect in the short run while eventually 
bearing fruit. We are personally sceptical of this explanation. Our main results measure intangible investment 2-4 years previous, and it seems unlikely that lags longer than that could yield overall positive investment results. Further, even when we cumulate investment over our entire period, we find a negative association with end-of-period productivity.

"Explanations" 6 - 8 are consistent with the data, but they are not really explanations in any fundamental sense: They suggest questions about how firms see their strategic choices, and why they choose the options that they do. But they are healthy reminders that firms are complex institutions that operate under their own objectives and constraints. Researchers' focus on productivity and profitability may not correspond even conceptually to the goals that firms and their owners pursue. And what firms seek and what they achieve may not necessarily be the same.

Because of these uncertainties, the policy implications of these findings seem limited. On one level, it is useful simply to remind ourselves that even with mounds of data we have only a cloudy lens through which to view firm behaviour. We can and should continue to try to understand better what is going on; but we should have no illusions that with enough data and the right econometrics we can produce The Answer.

These results do suggest that if productivity improvement is the goal, encouraging investment in the activities that we have considered is unlikely to be a powerful tool, at least without better understanding how intangible investment translates (or fails to translate) into intangible assets. This is a topic for further research, though there are inherent measurement difficulties.

If firms themselves are truly more focused on growth than on profitability, policy prescriptions become quite tricky. The standard formulation of seeking public policies that rectify market failures is predicated on the basic welfare economics optimality results, which in turn rest on the assumption of profit-maximizing behaviour. A model in which firms systematically seek growth rather than profits may well be realistic, but it requires a rethinking of the appropriate role for government. 
Finally, if firms systematically seek profits but systematically fail to use intangible investment effectively toward that end, then there are clearly some informational issues to be dealt with. Figuring out if policy could improve on this situation will require a better understanding of how and why firms make the decisions that they do. 


\section{References}

Aghion, P., Bloom, N., Blundell, R., Griffith, R., \& Howitt, P. (2002). Competition and Innovation: An Inverted U Relationship (Working Paper No. 9269). National Bureau of Economic Research.

Andrews, D., Criscuolo, C., \& Menon, C. (2014). Do Resources Flow to Patenting Firms? (OECD Economics Department Working Papers). Paris: Organisation for Economic Co-operation and Development.

Andrews, D., \& de Serres, A. (2012). Intangible Assets, Resource Allocation and Growth (OECD Economics Department Working Papers). Paris: Organisation for Economic Co-operation and Development.

Balasubramanian, N., \& Sivadasan, J. (2010). What Happens When Firms Patent? New Evidence from U.S. Economic Census Data. Review of Economics and Statistics, 93(1), 126-146.

Bontempi, M. E., \& Mairesse, J. (2015). Intangible capital and productivity at the firm level: a panel data assessment. Economics of Innovation and New Technology, 24(1-2), 22-51.

Corrado, C., Hulten, C., \& Sichel, D. (2005). Measuring capital and technology: an expanded framework. In Measuring capital in the new economy (pp. 11-46). University of Chicago Press.

Corrado, C., Hulten, C., \& Sichel, D. (2009). Intangible Capital and U.S. Economic Growth. Review of Income and Wealth, 55(3), 661-685.

Corrado, C. A., Haskel, J., Iommi, M., \& Jona Lasinio, C. (2012). Intangible capital and growth in advanced economies: Measurement and comparative results. Discussion Paper No. 6733, Institute for the Study of Labour (IZA), Bonn.

Crass, D., \& Peters, B. (2014). Intangible Assets and Firm-Level Productivity. Centre for European Research Discussion Paper No. 14-120.

Crepon, B., Duguet, E., \& Mairesse, J. (1998). Research, Innovation and Productivity: An Econometric Analysis At The Firm Level. Economics of Innovation and New Technology, 7(2), 115-158.

Fabling, R. (2011). Keeping it Together: Tracking Firms on New Zealand's Longitudinal Business Database. Motu Economic and Public Policy Research Working Papers 11_01.

Fabling, R., \& Maré, D. C. (2015a). Production Function Estimation Using New Zealand's Longitudinal Business Database. Motu Economic and Public Policy Research Working Papers 15_15. 
Fabling, R., \& Maré, D. C. (2015b). Addressing the absence of hours information in linked employeremployee data. Motu Economic and Public Policy Research Working Papers 15_17.

Fabling, R., \& Sanderson, L. (2016.). A Rough Guide to New Zealand's Longitudinal Business Database (2nd edition). Motu Economic and Public Policy Research Working Papers 16_03.

Firpo, S., Fortin, N. M., \& Lemieux, T. (2009). Unconditional quantile regressions. Econometrica, 77(3), 953-973.

Griliches, Z. (1979). Issues in assessing the contribution of research and development to productivity growth. The Bell Journal of Economics, 92-116.

Lin, H.L., \& Lo, M.L (2015). The portfolio of intangible investments and their performance: Evidence from Taiwanese Manufacturing Firms. Unpublished manuscript. Retrieved from http://homepage.ntu.edu.tw/ josephw/20151112 Intangible20151106v1.pdf

Maré, D. C (2016). Urban productivity estimation with heterogeneous prices and labour. Motu Economic and Public Policy Research Working Papers 16_21.

Machado, J. A. F., Parente, \& P. M., Silva, J. S. (2015). QREG2: Stata module to perform quantile regression with robust and clustered standard errors. Statistical Software Components.

Montresor, S., \& Vezzani, A. (2016). Intangible investments and innovation propensity: Evidence from the Innobarometer 2013. Industry and Innovation, 1-22.

Pakes, A., \& Griliches, Z. (1984). Patents and R\&D at the firm level: A first look. In Z. Griliches (Ed.), R\&D, Patents, and Productivity (ch. 3). Chicago: University of Chicago Press.

Scherer, F. M. (1982). Inter-industry technology flows and productivity growth. The Review of Economics and Statistics, 627-634.

Scherer, F. M. (1983). The propensity to patent. International Journal of Industrial Organization, 1(1), 107128.

Scherer, F. M. (1986). Innovation and growth: Schumpeterian perspectives. MIT Press Books, 1.

Webster, E. (2000). The growth of enterprise intangible investment in Australia. Information Economics and Policy, 12(1), 1-25. 


\section{Appendix}

Appendix Figure 1: Mean and spread of intangibles principal component, by industry

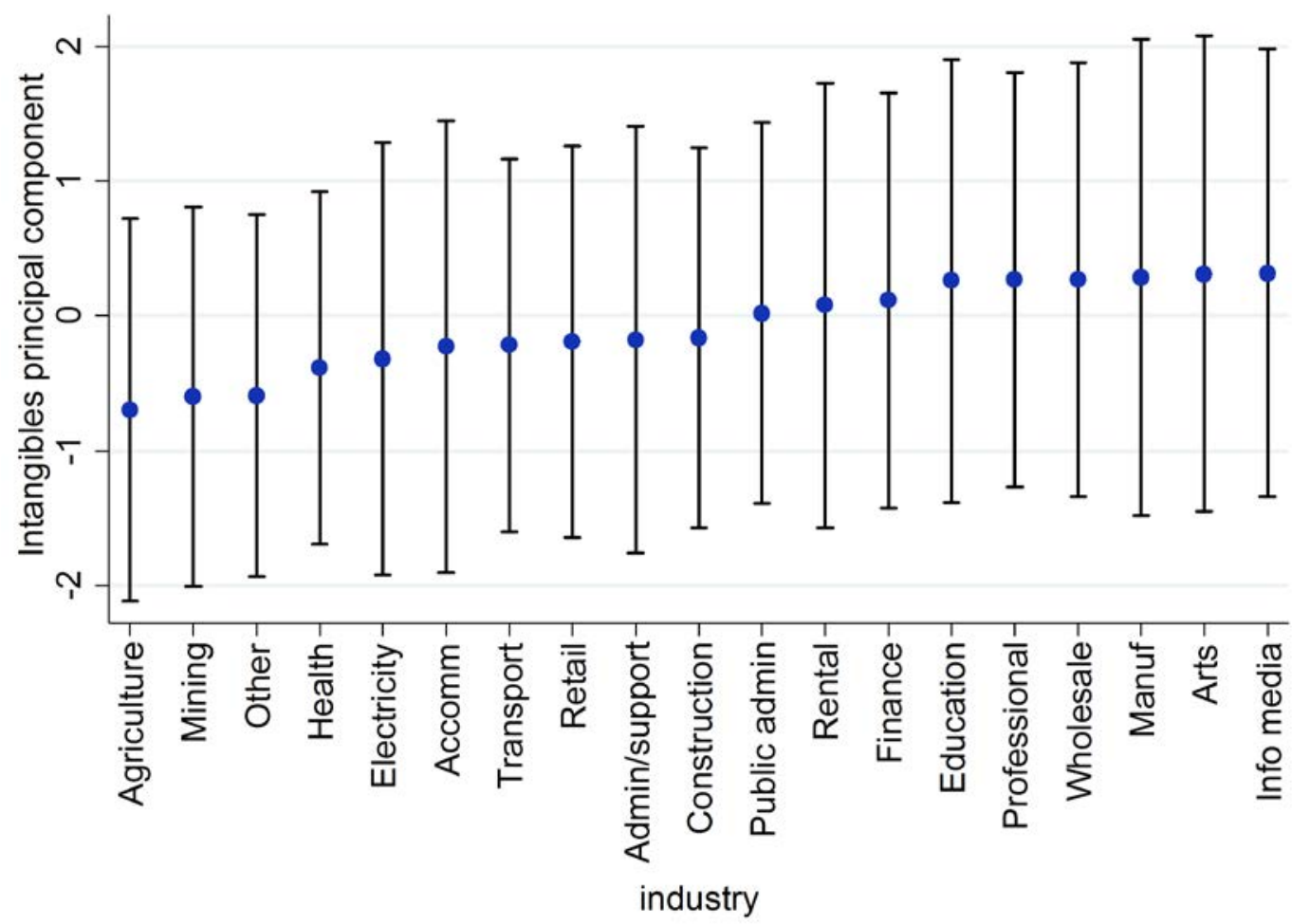

Notes: Appendix Figure 1 presents, as dots, the mean intangibles principal component for all firm-years by industry over the period 2005-2013. The bands show all values that fall within one standard deviation of the mean for each industry. Full industry descriptions are given in Appendix Table 3. 
Appendix Table 1: Correlation matrix of intangible indicators

\begin{tabular}{lccccccc}
\hline \hline & $\begin{array}{c}\text { Computer } \\
\text { ware }\end{array}$ & $\begin{array}{c}\text { New } \\
\text { business } \\
\text { strategies }\end{array}$ & $\begin{array}{c}\text { Organis. } \\
\text { restruct } \\
\text { uring }\end{array}$ & $\begin{array}{c}\text { Design } \\
\text { research }\end{array}$ & $\begin{array}{c}\text { Changes } \\
\text { to } \\
\text { mkting }\end{array}$ & $\begin{array}{c}\text { Employee } \\
\text { training }\end{array}$ \\
\hline $\begin{array}{l}\text { New business } \\
\text { strategies }\end{array}$ & 0.416 & & & & & \\
Organis. & 0.345 & 0.691 & & & & & \\
restructuring & 0.316 & 0.381 & 0.328 & & & & \\
Design & 0.327 & 0.474 & 0.389 & 0.445 & & & \\
Market research & 0.287 & 0.623 & 0.479 & 0.451 & 0.616 & & \\
Changes to mkting & 0.510 & 0.438 & 0.388 & 0.194 & 0.393 & 0.318 & \\
Employee training & 0.223 & 0.292 & 0.265 & 0.464 & 0.432 & 0.282 & 0.186 \\
R\&D & & & & & & \\
\hline
\end{tabular}

Notes: Tetrachoric correlations are derived from the cross-section of all innovation BOS modules, 2005-

2013. Descriptions are abbreviated. See Section 3.1 for full descriptions.

Appendix Table 2: Principal components of intangibles indicators

\begin{tabular}{lcc}
\hline \hline & $\begin{array}{c}\text { 1st component } \\
\text { weights }\end{array}$ & $\begin{array}{c}\text { 2nd component } \\
\text { weights }\end{array}$ \\
\hline $\begin{array}{l}\text { Acquisition of computer hardware \& software } \\
\text { Implementing new business strategies/management }\end{array}$ & 0.312 & -0.372 \\
techniques & 0.416 & -0.181 \\
Organisational restructuring & 0.373 & -0.207 \\
Design & 0.330 & 0.452 \\
Market research & 0.387 & 0.209 \\
Significant changes to marketing strategies & 0.393 & 0.108 \\
Employee training & 0.315 & -0.489 \\
Research and development & 0.280 & 0.536 \\
\hline
\end{tabular}

Notes: The two components with eigenvalues larger than 1 are shown. Principal components are derived from the tetrachoric correlation matrix that is shown in

Appendix Table 1. 
Appendix Table 3: ANZSIC 2006 industry codes

\begin{tabular}{lll}
\hline \hline Code & Industry description & Abbreviation \\
\hline A & Agriculture, Forestry and Fishing & Agriculture \\
B & Mining & Mining \\
C & Manufacturing & Manuf \\
D & Electricity, Gas, Water and Waste Services & Electricity \\
E & Construction & Construction \\
F & Wholesale Trade & Wholesale \\
G & Retail Trade & Retail \\
H & Accommodation and Food Services & Accomm \\
I & Transport, Postal and Warehousing & Transport \\
J & Information Media and Telecommunications & Info media \\
K & Financial and Insurance Services & Finance \\
L & Rental, Hiring and Real Estate Services & Rental \\
M & Professional, Scientific and Technical Services & Professional \\
N & Administrative and Support Services & Admin/support \\
O & Public Administration and Safety & Public admin \\
P & Education and Training & Education \\
Q & Health Care and Social Assistance & Health \\
R & Arts and Recreation Services & Arts \\
S & Other Services & Other \\
\hline
\end{tabular}

Notes: Codes and industry descriptions come from Statistics NZ. Abbreviations are the authors' own. 
Appendix Table 4: Intangibles by industry, controlling for firm size

\begin{tabular}{|c|c|}
\hline Variable & intangibles index \\
\hline Full-time equivalent (ln) (2-yr lagged) & $\begin{array}{c}0.044^{* * *} \\
(0.001)\end{array}$ \\
\hline Agriculture & $\begin{array}{c}-0.064^{* * *} \\
(0.010)\end{array}$ \\
\hline Mining & $\begin{array}{c}-0.052^{* * *} \\
(0.017)\end{array}$ \\
\hline Manuf & $\begin{array}{c}0.058^{* * *} \\
(0.009)\end{array}$ \\
\hline Electricity & $\begin{array}{c}0.008 \\
(0.017)\end{array}$ \\
\hline Construction & $\begin{array}{l}-0.016 \\
(0.011)\end{array}$ \\
\hline Wholesale & $\begin{array}{c}0.049 * * * \\
(0.011)\end{array}$ \\
\hline Retail & $\begin{array}{c}-0.041^{* * * *} \\
(0.011)\end{array}$ \\
\hline Accomm & $\begin{array}{l}-0.021^{*} \\
(0.013)\end{array}$ \\
\hline Transport & $\begin{array}{c}-0.047^{* * *} \\
(0.011)\end{array}$ \\
\hline Info media & $\begin{array}{c}0.081^{* * *} \\
(0.013)\end{array}$ \\
\hline Finance & $\begin{array}{c}0.051^{* * *} \\
(0.011)\end{array}$ \\
\hline Rental & $\begin{array}{c}0.042^{* * *} \\
(0.013)\end{array}$ \\
\hline Professional & $\begin{array}{c}0.057^{* * *} \\
(0.010)\end{array}$ \\
\hline Admin/support (omitted) & - \\
\hline Public admin & $\begin{array}{c}0.008 \\
(0.037)\end{array}$ \\
\hline Education & $\begin{array}{c}0.079 * * * \\
(0.016)\end{array}$ \\
\hline Health & $\begin{array}{c}-0.044^{* * *} \\
(0.011)\end{array}$ \\
\hline Arts & $\begin{array}{c}0.067^{* * *} \\
(0.019)\end{array}$ \\
\hline Other & $\begin{array}{c}-0.029^{* *} \\
(0.014)\end{array}$ \\
\hline Observations & 29,547 \\
\hline$R$-squared & 0.090 \\
\hline
\end{tabular}

Notes: This table regresses a firm's intangibles index on previous firm size and industry dummy variables. Full industry descriptions are given in Appendix Table 1. The reported numbers of observations have been randomly rounded to the nearest multiple of 3 , as required by Statistics NZ confidentiality rules. Asterisks denote: ${ }^{* * *} \mathrm{p}<0.01,{ }^{* *} \mathrm{p}<0.05$, * $\mathrm{p}<0.10$. 
Appendix Table 5: Sample statistics of regression variables

\begin{tabular}{|c|c|c|c|c|c|c|}
\hline & mean & $\begin{array}{l}\text { std. } \\
\text { deviati } \\
\text { on }\end{array}$ & median & $\begin{array}{l}1 \text { st } \\
\text { percen } \\
\text { tile }\end{array}$ & $\begin{array}{l}\text { 99th } \\
\text { perce } \\
\text { ntile } \\
\end{array}$ & $\begin{array}{l}\text { obs. } \\
\text { count }\end{array}$ \\
\hline Log FTE labour & 3.22 & 1.29 & 3.12 & 0.88 & 6.74 & 31,377 \\
\hline \multicolumn{7}{|l|}{ Age categories: } \\
\hline Age $<=1$ & 0.03 & 0.18 & 0 & 0 & 1 & 31,377 \\
\hline Age 2-5 & 0.17 & 0.38 & 0 & 0 & 1 & 31,377 \\
\hline Age 6-10 & 0.22 & 0.41 & 0 & 0 & 1 & 31,377 \\
\hline Age $11-20$ & 0.30 & 0.46 & 0 & 0 & 1 & 31,377 \\
\hline Age 21+ & 0.27 & 0.44 & 0 & 0 & 1 & 31,377 \\
\hline \multicolumn{7}{|l|}{ Market power categories: } \\
\hline Captive market & 0.04 & 0.20 & 0 & 0 & 1 & 30,516 \\
\hline 1 or 2 competitors & 0.18 & 0.39 & 0 & 0 & 1 & 30,516 \\
\hline Many competitors, some dominant & 0.56 & 0.50 & 1 & 0 & 1 & 30,516 \\
\hline Many competitors, none dominant & 0.18 & 0.39 & 0 & 0 & 1 & 30,516 \\
\hline Doesn't know competition & 0.04 & 0.19 & 0 & 0 & 1 & 30,516 \\
\hline Log age & 2.44 & 0.92 & 2.56 & 0 & 4.42 & 31,158 \\
\hline Intangibles index $(0-1)$ & 0.40 & 0.25 & 0.38 & 0 & 1.00 & 27,396 \\
\hline Doesn't-know intangibles index $(0-1)$ & 0.03 & 0.12 & 0 & 0 & 0.88 & 27,396 \\
\hline Any intangible expenditure & 0.33 & 0.47 & 0 & 0 & 1 & 23,142 \\
\hline Log intangible expenditure & 10.86 & 2.25 & 10.82 & 4.61 & 16.22 & 7,563 \\
\hline Log gross output & 15.25 & 1.62 & 15.08 & 12.21 & 19.75 & 17,703 \\
\hline Log capital & 12.78 & 1.78 & 12.69 & 8.59 & 17.64 & 17,703 \\
\hline Log labour & 3.34 & 1.30 & 3.22 & 1.09 & 6.86 & 17,703 \\
\hline Log materials & 14.31 & 1.87 & 14.16 & 10.25 & 19.18 & 17,703 \\
\hline $\begin{array}{l}\text { MFP residual (gross output translog } \\
\text { spec) }\end{array}$ & 0.00 & 0.37 & 0 & -1.07 & 1.02 & 17,703 \\
\hline Change in MFP residual & -0.01 & 0.29 & -0.01 & -0.81 & 0.83 & 8,244 \\
\hline$>5 \%$ increase in MFP & 0.31 & 0.46 & 0 & 0 & 1 & 8,244 \\
\hline Log profitability (profit/capital) & 0.76 & 1.10 & 0.73 & -2.35 & 3.53 & 15,339 \\
\hline Change in log profitability & -0.17 & 0.91 & -0.13 & -2.97 & 2.46 & 6,699 \\
\hline$>5 \%$ increase in profitability & 0.37 & 0.48 & 0.00 & 0.00 & 1.00 & 6,699 \\
\hline Log labour productivity & 11.20 & 0.74 & 11.19 & 9.12 & 13.34 & 17,466 \\
\hline Change in log labour productivity & -0.02 & 0.49 & -0.01 & -1.62 & 1.48 & 8,100 \\
\hline$>5 \%$ increase in labour productivity & 0.38 & 0.49 & 0 & 0 & 1 & 8,100 \\
\hline Log profit & 13.62 & 1.78 & 13.51 & 9.65 & 18.47 & 15,339 \\
\hline Change in log profit & -0.14 & 0.87 & -0.10 & -2.86 & 2.33 & 6,699 \\
\hline$>5 \%$ increase in profit & 0.37 & 0.48 & 0 & 0 & 1 & 6,699 \\
\hline$>25 \%$ increase in profit & 0.26 & 0.44 & 0 & 0 & 1 & 6,699 \\
\hline $\begin{array}{l}\text { Output growth } 4-2 \text { years ago relative } \\
\text { to industry avg }\end{array}$ & 0.03 & 0.52 & 0.03 & -1.46 & 1.48 & 6,321 \\
\hline Confidence index & 2.37 & 0.36 & 2.33 & 1.50 & 3.00 & 28,101 \\
\hline Customers perceived as satisfied & 0.62 & 0.49 & 1 & 0 & 1 & 26,892 \\
\hline Employees perceived as satisfied & 0.49 & 0.50 & 0 & 0 & 1 & 25,716 \\
\hline \multicolumn{7}{|c|}{$\begin{array}{l}\text { Notes: This table presents summary statistics for regression variables in this paper. Limited to } \\
\text { firm-years appearing in the BOS innovation survey in the years 2005, 2007, 2009, } 2011 \text { or } \\
\text { 2013. The 1st and 99th percentiles are reported rather than minimum and maximum values, to } \\
\text { abide by Statistics NZ confidentiality rules. The reported numbers of observations have been } \\
\text { randomly rounded to the nearest multiple of 3, as required by Statistics NZ confidentiality } \\
\text { rules. }\end{array}$} \\
\hline
\end{tabular}


Appendix Table 6: Characteristics of intangibles-investing firms, robustness check

\begin{tabular}{|c|c|c|c|c|c|c|}
\hline Dependent variable: & $\begin{array}{c}\text { Intangibles } \\
\text { principal } \\
\text { component }\end{array}$ & $\begin{array}{c}\text { Intangibles } \\
\text { principal } \\
\text { component }\end{array}$ & $\begin{array}{c}\text { Intangibles } \\
\text { principal } \\
\text { component }\end{array}$ & $\begin{array}{c}\text { Intangible } \\
\text { expenditure } \\
(\ln ) \\
\end{array}$ & $\begin{array}{c}\text { Intangible } \\
\text { expenditure } \\
(\ln ) \\
\end{array}$ & $\begin{array}{c}\text { Intangible } \\
\text { expenditure } \\
(\ln ) \\
\end{array}$ \\
\hline Full time equivalent $(\ln )$ (2-yr lagged) & $\begin{array}{c}0.375^{* * *} \\
(0.014)\end{array}$ & $\begin{array}{c}0.408^{* * *} \\
(0.017)\end{array}$ & $\begin{array}{c}0.082 \\
(0.060)\end{array}$ & $\begin{array}{c}0.409^{* * *} \\
(0.017)\end{array}$ & $\begin{array}{c}0.439^{* * *} \\
(0.020)\end{array}$ & $\begin{array}{c}0.221^{*} \\
(0.126)\end{array}$ \\
\hline Output growth $4-2$ yrs ago relative to industry & & $\begin{array}{c}0.130^{* * *} \\
(0.039)\end{array}$ & & & $\begin{array}{c}0.019 \\
(0.056)\end{array}$ & \\
\hline Age $<2$ (2-yr lagged $)$ & $\begin{array}{c}0.197^{* * *} \\
(0.076)\end{array}$ & $\begin{array}{c}0.194 \\
(0.178)\end{array}$ & & $\begin{array}{c}0.059 \\
(0.126)\end{array}$ & $\begin{array}{c}-0.516 \\
(0.400)\end{array}$ & \\
\hline Age 2-5 (2-yr lagged) & $\begin{array}{c}0.071^{*} \\
(0.039)\end{array}$ & $\begin{array}{c}0.097^{*} \\
(0.054)\end{array}$ & & $\begin{array}{c}-0.011 \\
(0.055)\end{array}$ & $\begin{array}{c}-0.117 \\
(0.076)\end{array}$ & \\
\hline Age 11-20 (2-yr lagged) & $\begin{array}{c}-0.073^{* *} \\
(0.037)\end{array}$ & $\begin{array}{c}-0.065 \\
(0.048)\end{array}$ & & $\begin{array}{c}0.030 \\
(0.046)\end{array}$ & $\begin{array}{c}0.002 \\
(0.062)\end{array}$ & \\
\hline Age $21+(2$-yr lagged $)$ & $\begin{array}{c}-0.042 \\
(0.042)\end{array}$ & $\begin{array}{c}0.027 \\
(0.053)\end{array}$ & & $\begin{array}{l}-0.025 \\
(0.050)\end{array}$ & $\begin{array}{l}-0.086 \\
(0.065)\end{array}$ & \\
\hline Log of age (2-yr lagged) & & & $\begin{array}{c}-0.001 \\
(0.069)\end{array}$ & & & $\begin{array}{c}0.261 \\
(0.200)\end{array}$ \\
\hline Perceived captive market (2-yr lagged) & $\begin{array}{c}-0.340^{* * *} \\
(0.072)\end{array}$ & $\begin{array}{c}-0.270^{* * *} \\
(0.094)\end{array}$ & $\begin{array}{c}-0.083 \\
(0.098)\end{array}$ & $\begin{array}{c}0.028 \\
(0.103)\end{array}$ & $\begin{array}{c}0.085 \\
(0.165)\end{array}$ & $\begin{array}{c}-0.217 \\
(0.248)\end{array}$ \\
\hline 1 or 2 competitors (2-yr lagged) & $\begin{array}{c}-0.002 \\
(0.037)\end{array}$ & $\begin{array}{c}-0.041 \\
(0.048)\end{array}$ & $\begin{array}{c}0.076 \\
(0.049)\end{array}$ & $\begin{array}{c}0.050 \\
(0.045)\end{array}$ & $\begin{array}{c}0.071 \\
(0.062)\end{array}$ & $\begin{array}{l}-0.244^{* *} \\
(0.119)\end{array}$ \\
\hline Many competitors, none dominant (2-yr lagged) & $\begin{array}{c}-0.087^{* *} \\
(0.034)\end{array}$ & $\begin{array}{c}-0.033 \\
(0.045)\end{array}$ & $\begin{array}{c}-0.008 \\
(0.040)\end{array}$ & $\begin{array}{c}0.010 \\
(0.042)\end{array}$ & $\begin{array}{c}0.018 \\
(0.054)\end{array}$ & $\begin{array}{c}-0.001 \\
(0.087)\end{array}$ \\
\hline Doesn't know competition (2-yr lagged) & $\begin{array}{c}-0.616^{* * *} \\
(0.082)\end{array}$ & $\begin{array}{c}-0.454^{* * *} \\
(0.106)\end{array}$ & $\begin{array}{c}0.183^{*} \\
(0.103)\end{array}$ & $\begin{array}{c}0.090 \\
(0.084)\end{array}$ & $\begin{array}{c}0.114 \\
(0.129)\end{array}$ & $\begin{array}{c}-0.135 \\
(0.306)\end{array}$ \\
\hline $\begin{array}{l}\text { Year * level } 3 \text { industry FE } \\
\text { Firm FE }\end{array}$ & Yes & Yes & $\begin{array}{l}\text { Yes } \\
\text { Yes }\end{array}$ & Yes & Yes & $\begin{array}{l}\text { Yes } \\
\text { Yes }\end{array}$ \\
\hline Observations & 15,615 & 9,363 & 15,519 & 8,136 & 5,094 & 5,271 \\
\hline R squared & 0.213 & 0.260 & 0.079 & 0.950 & 0.952 & 0.215 \\
\hline
\end{tabular}

Notes: This table presents the coefficients from OLS regressions at the firm-year level, where the dependent variable is an intangibles measure that is described in each column header. The sample is limited to March-years from 2005 to 2013. In columns (4) to (6) the sample is limited to firms with positive reported intangible investment. The omitted category for age is 6-10 years, and the omitted category for competition is 'many competitors, some dominant'. Standard errors, in

parentheses, are robust and clustered at the firm level. The reported numbers of observations have been randomly rounded to the nearest multiple of 3 , as required by Statistics NZ confidentiality rules. Asterisks denote: ${ }^{* * *} \mathrm{p}<0.01,{ }^{* *} \mathrm{p}<0.05,{ }^{*} \mathrm{p}<0.10$. 
Appendix Table 7: Absolute profits and past intangible investment

\begin{tabular}{|c|c|c|c|c|}
\hline Dependent variable: & $\begin{array}{l}\text { Absolute } \\
\text { profit (ln) } \\
\text { (1) }\end{array}$ & $\begin{array}{l}\text { 2-yr log difference in } \\
\text { absolute profit } \\
\text { (2) }\end{array}$ & $\begin{array}{l}\text { Indicator for } \\
>5 \% \text { increase } \\
\text { in abs. profit } \\
\text { (3) }\end{array}$ & $\begin{array}{l}\text { Indicator for } \\
>25 \% \text { increase in } \\
\text { abs. profit } \\
\text { (4) }\end{array}$ \\
\hline Intangibles index (2-yr lagged) & $\begin{array}{c}1.480 * * * \\
(0.097)\end{array}$ & $\begin{array}{c}0.053 \\
(0.050)\end{array}$ & $\begin{array}{c}0.095^{* * *} \\
(0.028)\end{array}$ & $\begin{array}{c}0.100 * * * \\
(0.026)\end{array}$ \\
\hline $\begin{array}{l}\text { Doesn't-know intang. index (2-yr } \\
\text { lagged) }\end{array}$ & $\begin{array}{c}0.561^{* * *} \\
(0.207)\end{array}$ & $\begin{array}{l}-0.090 \\
(0.102)\end{array}$ & $\begin{array}{c}0.049 \\
(0.060)\end{array}$ & $\begin{array}{c}0.046 \\
(0.054)\end{array}$ \\
\hline Age $2-5$ & $\begin{array}{c}-0.226^{* * *} \\
(0.079)\end{array}$ & $\begin{array}{c}0.062 \\
(0.048)\end{array}$ & $\begin{array}{c}0.000 \\
(0.026)\end{array}$ & $\begin{array}{c}0.031 \\
(0.024)\end{array}$ \\
\hline Age 11-20 & $\begin{array}{c}0.264 * * * \\
(0.060)\end{array}$ & $\begin{array}{l}-0.041 \\
(0.032)\end{array}$ & $\begin{array}{c}-0.048 * * * \\
(0.018)\end{array}$ & $\begin{array}{l}-0.029 * \\
(0.016)\end{array}$ \\
\hline Age 21+ & $\begin{array}{c}0.595 * * * \\
(0.065)\end{array}$ & $\begin{array}{c}-0.079 * * * \\
(0.031)\end{array}$ & $\begin{array}{c}-0.069 * * * \\
(0.018)\end{array}$ & $\begin{array}{c}-0.063^{* * *} \\
(0.016)\end{array}$ \\
\hline Perceived captive market & $\begin{array}{l}-0.200 \\
(0.141)\end{array}$ & $\begin{array}{l}-0.031 \\
(0.057)\end{array}$ & $\begin{array}{c}0.006 \\
(0.042)\end{array}$ & $\begin{array}{l}-0.037 \\
(0.035)\end{array}$ \\
\hline Perceived 1 or 2 competitors & $\begin{array}{c}-0.158 * * \\
(0.063)\end{array}$ & $\begin{array}{l}0.055^{*} \\
(0.032)\end{array}$ & $\begin{array}{c}0.025 \\
(0.017)\end{array}$ & $\begin{array}{c}0.020 \\
(0.016)\end{array}$ \\
\hline $\begin{array}{l}\text { Perceived many competitors, none } \\
\text { dominant }\end{array}$ & $\begin{array}{c}-0.210^{* * *} \\
(0.055)\end{array}$ & $\begin{array}{l}0.010 \\
(0.032)\end{array}$ & $\begin{array}{l}-0.005 \\
(0.018)\end{array}$ & $\begin{array}{c}0.001 \\
(0.016)\end{array}$ \\
\hline Doesn't know competition & $\begin{array}{c}-0.386^{* * *} \\
(0.124)\end{array}$ & $\begin{array}{c}0.085 \\
(0.066)\end{array}$ & $\begin{array}{c}0.007 \\
(0.039)\end{array}$ & $\begin{array}{l}-0.029 \\
(0.034)\end{array}$ \\
\hline Year * level 3 industry FE & Yes & Yes & Yes & Yes \\
\hline Observations & 6,762 & 5,673 & 5,673 & 5,673 \\
\hline Proportion of successes & & & 0.371 & 0.262 \\
\hline$R$ squared & 0.377 & 0.160 & 0.160 & 0.169 \\
\hline
\end{tabular}

Notes: This table presents the coefficients from OLS regressions at the firm-year level, where the dependent variable is described in column headers. The omitted category for age is '6-10 years', and the omitted category for competition is 'many competitors, some dominant'. The sample is limited to odd March-years from 2005 to 2013. Standard errors, in parentheses, are robust and clustered at the firm level. The reported numbers of observations have been randomly rounded to the nearest multiple of 3, as required by Statistics NZ confidentiality rules. Asterisks denote: ${ }^{* *} \mathrm{p}<0.01,{ }^{* *} \mathrm{p}<0.05{ }^{*} \mathrm{p}<0.10$. 
Appendix Table 8: Intangible investment and customer/employee satisfaction, logit regression

\begin{tabular}{|c|c|c|c|c|c|c|}
\hline Dependent variable: & $\begin{array}{c}\text { High } \\
\text { customer } \\
\text { satisfaction } \\
\text { (1) } \\
\end{array}$ & $\begin{array}{c}\text { High } \\
\text { customer } \\
\text { satisfaction } \\
\text { (2) }\end{array}$ & $\begin{array}{c}\text { High } \\
\text { customer } \\
\text { satisfaction } \\
\text { (3) }\end{array}$ & $\begin{array}{c}\text { High } \\
\text { employee } \\
\text { satisfaction } \\
\text { (4) }\end{array}$ & $\begin{array}{c}\text { High } \\
\text { employee } \\
\text { satisfaction } \\
\text { (5) }\end{array}$ & $\begin{array}{c}\text { High } \\
\text { employee } \\
\text { satisfaction } \\
\text { (6) }\end{array}$ \\
\hline Intangibles index (2-yr lagged) & $\begin{array}{c}0.091^{* * *} \\
(0.020)\end{array}$ & $\begin{array}{c}0.047^{* * *} \\
(0.018)\end{array}$ & $\begin{array}{c}0.007 \\
(0.016)\end{array}$ & $\begin{array}{l}0.084^{* * *} \\
(0.021)\end{array}$ & $\begin{array}{c}0.058^{* * *} \\
(0.020)\end{array}$ & $\begin{array}{l}0.036^{*} \\
(0.019)\end{array}$ \\
\hline Doesn't-know intangibles index (2-yr lagged) & $\begin{array}{c}-0.119 * * * \\
(0.043)\end{array}$ & $\begin{array}{c}-0.114^{* * *} \\
(0.038)\end{array}$ & $\begin{array}{c}-0.084^{* *} \\
(0.033)\end{array}$ & $\begin{array}{c}-0.114^{* *} \\
(0.038)\end{array}$ & $\begin{array}{c}-0.110^{* *} \\
(0.045)\end{array}$ & $\begin{array}{c}-0.088^{* *} \\
(0.043)\end{array}$ \\
\hline Confidence index $(1-3)$ & & $\begin{array}{c}0.573^{* * *} \\
(0.011)\end{array}$ & & & $\begin{array}{c}0.414^{* * *} \\
(0.013)\end{array}$ & \\
\hline $\begin{array}{l}\text { Dummy variables for reported costs, time to } \\
\text { provide g\&s, quality and flexibility }\end{array}$ & & & Yes & & & Yes \\
\hline Year \& level 3 industry FE & Yes & Yes & Yes & Yes & Yes & Yes \\
\hline Proportion of successes & 0.628 & 0.628 & 0.627 & 0.494 & 0.493 & 0.493 \\
\hline Observations & 13,248 & 13,224 & 13,128 & 12,597 & 12,564 & 12,480 \\
\hline
\end{tabular}

Notes: This table presents average marginal effects from logit regressions at the firm-year level, where the dependent variable is a dummy variable for the

firm reporting an aspect of soft success, as described in column headers. Marginal effects are for a discrete change of 1 unit, because our indices are not continuous. The sample is limited to March-years from 2005 to 2013. Standard errors, in parentheses, are robust and clustered at the firm level. The reported numbers of observations have been randomly rounded to the nearest multiple of 3, as required by Statistics NZ confidentiality rules. Asterisks denote: ${ }^{* * *} \mathrm{p}<0.01,{ }^{* *} \mathrm{p}<0.05,{ }^{*} \mathrm{p}<0.10$. 